\title{
Geochemistry Studies Pertaining to the G-Tunnel Radionuclide Migration Field Experiment
}

A. E. Norris

R. D. Aguilar

B. P. Bayhurst

D. L. Bish

M. F. Cisneros

W. R. Daniels

C. J. Dutfy

R. D. Golding*

S. L. Jensen*

S. D. Knight

F. O. Lawrence

S. Maestas

A. J. Mitchell

P. Q. Oliver

N. A. Raybold

R. S. Rundberg

G. M. Thompson*

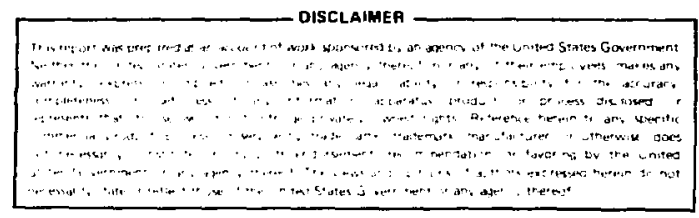
E. N. Treher
B. J. Travis
G. R. Walter*
R. G. Warren
K. Woltsberg 


\section{CONTENTS}

ABSTKACT . . . . . . . . . . . . . . . . . . . . . . . . . . . . 1

I. INTRODUCTION . . . . . . . . . . . . . . . . . . . . . . . . . . . . 1

II. TUNNEL BED TUFF CHARACTERIZATION . . . . . . . . . . . . . . . . . . 2

A. X-Ray Diffraction Analyses. . . . . . . . . . . . . . . . . . 2

B. Thin Section Examinations . . . . . . . . . . . . . . . . . . 2

C. Measurements of Permeability, Porosity, and Diffusion

1 II. WATER PREPARATION AND ClIARACTERIZATION . . . . . . . . . . . . . . . 6

A. Selection of Water and Rock Sources . . . . . . . . . . . . . . 6

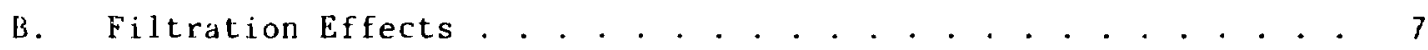

C. Effects of Contact Time . . . . . . . . . . . . . . . . . . . . 9

D. Effects of Standing Time and Acidification on Cation Analysis . 10

E. Tritium Content of Water in Tuff from Core U12G-RNM9 . . . . . . 12

IV. BATCH SORFTIUN EXPERIMENTS . . . . . . . . . . . . . . . . . . . . . 12

A. Crushed-Tuff Matrix . . . . . . . . . . . . . . . . . . 12

B. Crushed Fracture-Fill Material . . . . . . . . . . . . . . . . 14

C. Wafers... . . . . . . . . . . . . . . . . . . . . 16

V. COLUNIN SORPTION STUDIES . . . . . . . . . . . . . . . . . . . . . . 20

A. Crushed Fracture-Fill Column . . . . . . . . . . . . . . . . . 20

B. Solid-Core Column . . . . . . . . . . . . . . . . . . . . . . 23

VI. ACTINIDE SORPTION MEASUREMENTS . . . . . . . . . . . . . . . . . . . . . . 27

A. Uranium Sorption . . . . . . . . . . . . . . . . . . . 27

B. Neptunium, Plutonium, and Americium Sorption . . . . . . . . . . 28

VII. CALClLATIONS OF RADIONUCLIDE MIGRATION IN FRACTURED TUFF . . . . . . 30

A. One-Dimensional Fracture-Flow with Matrix Diffusion . . . . . . 30

B. TRACR3D . . . . . . . . . . . . . . . . . . . . . . 38

VIII. CONCLUSIONS . . . . . . . . . . . . . . . . . . . . . . 39

REFERENCES . . . . . . . . . . . . . . . . . . . . . . . . . . 42 
GEOCHEMISTRY STUDIES PERTAINING TO THE G-TUNNEL

RADIONUCLIDE MIGRATION FIELD EXPERIMENT

by

A. E. Norris, R. D. Aguilar, B. P. Bayhurst, D. L. Bish, M. R. Cisneros, W. R. Daniels, C. J. Duffy, R. D. Golding,

S. L. Jensen, S. D. Knight, F. O. Lawrence, S. Maestas, A. J. Mitchell, P. Q. Oliver, N. A. Raybold, R. S. Rundberg, G. M. Thompson, E. N. Treher, B. J. Travis, G. R. Walter, R. G. Warren, and $K$. Wolfsberg

\begin{abstract}
This report presents the results of geochemical studies of Tunnel Bed tuff that were performed by Los Alamos National Laboratory or done at its direction as part of the Nevada Test Site G-Tunnel Radionuclide Migration Field Experiment. A tuff-treated water was prepared and used in laboratoryscale measurements of radionuclide sorption onto crushed Tunnel Bed tuff, pulverized fracture-fill material, tuff wafers, and a solid tuff core. Modelling studies were undertaken to determine the effects of matrix diffusion and unsaturated tuff on the proposed fracture-flow experiments. The initial results of those studies are presented in this report.
\end{abstract}

I. INTRODUCTION

Los Alamos National Laboratory, Argonne National Laboratory, and Sandia National Laboratories jointly undertook a program to conduct smal1-scale, atdepth radionuclide migration experiments in $G$ Tunnel at the Nevada Test Site (NTS). The geochemical properties of a particular G-Tunnel formation, Tunnel 
Bed 5 tuff, were studied in work directed by Los Alamos to determine whether a successful field migration experiment could be performed in that medium. This report outlines the results of that study.

The major part of this work was devoted to measuring the sorption of radionuclides onto Tunnel Bed tuff. Before these experiments could be undertaken, however, it was necessary to prepare an appropriate water for use in the sorption measurements. The studies related to the preparation of a tuff-treated water that is in approximate equilibrium with the Tunnel Bed tuff are given in this report. The results of batch measurements of radionuclide sorption onto crushed tuff, pulverized fracture-fill material, and wafers are given in Sec. IV. The following section lists the results of column measurements of radionuclide sorption onto pulverized fracture-fili material and onto a solid core of tuff. The next section contains actinide sorption results. The final section of this report discusses the use of two geochemical models to calculate radionuclide sorption during a fracture-flow field experiment. One model emphasizes matrix diffusion effects in a one-dimensional calculation. The second model is more general, but its use for fracture-flow studies is just beginning.

I I. TUNNEL BED TUFF CHARACTERIZATION

A. X-Ray Diffraction Analyses

The material used for the sorption studies described in this report is Tunnel Bed 5 tuff. On the whole, the Tunnel Beds consist of medium to massive bedded ash-fall tuff. The tuff is light brown to reddish brown. It is fine to medium grained, and it is generally zeolitized. ${ }^{1} \mathrm{X}$-ray diffraction studies were performed on crushed-tuff samples from Tunnel Bed 5. Additional x-ray analyses were performed on fracture-fill material obtained from nearby fractures. The results of these analyses are given in Table I. The fracture-fill material was found to be virtually indistinguishable from the crushed-matrix sample.

\section{B. Thin Section Examinations}

Thin sections from hoth sides of a parting plane in the U12G-RNM9 core were examined microscopically. The mineralogy was not determined, but the two sides were found to be distinctly different on a textural basis. A section of U12G-RNM9, 5.9 to $6.4 \mathrm{ft}$, Side B, shows a zone of low porosity, 
TABLE I

$X$-RAY DIFFRACTION ANALYSES

OF TUNNEL BED 5 MATERIAL

\begin{tabular}{|c|c|c|c|}
\hline \multirow[b]{2}{*}{ Description } & \multicolumn{3}{|c|}{$\begin{array}{c}\begin{array}{c}\text { Volume } \\
(\%)\end{array} \\
\end{array}$} \\
\hline & Clinoptilolite & $\underline{K-f e l d s p a r}$ & Illite/Mica \\
\hline $\begin{array}{l}\text { U12G-RNM9, } 10.8 \text { to } 11.9 \mathrm{ft} \text {, } \\
\text { matrix }\end{array}$ & $70-90$ & $10-20$ & $5-10$ \\
\hline $\begin{array}{l}\mathrm{U} 12 \mathrm{C}-\mathrm{RMM} 9,0.8 \text { to } 1.0 \mathrm{ft} \text {. } \\
\text { fracture fill }\end{array}$ & $60-80$ & $20-40$ & trace \\
\hline $\begin{array}{l}\mathrm{U} 12 \mathrm{G}-\mathrm{RNM} 9,7.1 \text { to } 8.1 \mathrm{ft}, \\
\text { fracture fill }\end{array}$ & $60-80$ & $20-40$ & trace \\
\hline
\end{tabular}

about $3 \mathrm{~mm}$ wide, adjacent to the parting plane. The remainder of the section has considerably higher porosity. Side A of a section of U12G-RNM9, 5.9 to $6.4 \mathrm{ft}$, shows no regular change in porosity across the section. Thus, the porosity of the tuff adjacent to a parting plane exhibited asymmetrical porosity characteristics. An examination of the G-Tunnel location from which the core was taken indicated that Side $B$ is the lower side of the fracture. C. Measurements of Permeability, Porosity, and Diffusion Coefficients

The permeabilities and porosity of five samples were measured. The permeability was first measured at a low effective confining pressure of 2 to 3 MPa. The confining pressure was raised to a maximum, and a series of measurements was made at successively lower confining pressures. No appreciable changes in permeability were observed as a result of this pressure cycle. The ranges of the individual permeability measurements are listed in Table II. These samples were weighed twice: after the permeability measurements and again after thorough drying. The net mass of water in each sample was used to calculate the porosity of each sample. These results are shown in Table II.

Porosities of Tunnel Bed tuff samples were measured in two other ways. A mercury infusion porosimeter was used to measure porosities caused by pores with diameters $>0.1 \mu \mathrm{m}$. This limit is set by the maximum operating pressure of the porosimeter, which is $1.4 \mathrm{MPa}$. The results of these measurements are shown in the first column of data in Table III. The other method used to measure porosities is based on measurements of grain densities that are taken 
TABLE II

MEASURED PERMEABILITIES AND POROSITIES OF

U12G-RNM9, 5.9 to 6.4 FT, TUFF SAMPLES

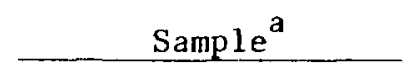

Side A, Position A

Side A, Position B

Side A, Position C

Side B, Position A

Side B, Position B

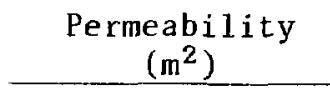

(2 to 8 ) $\times 10^{-19}$

(3 to 6) $\times 10^{-19}$

(3 to 9 ) $\times 10^{-19}$

(1 to 4$) \times 10^{-18}$

(1 to 3$) \times 10^{-18}$
Porosity

0.39

0.39

0.31

0.39

0.37

${ }^{a}$ Side $A$ is above the bedding plane; side $B$ is below.

TABLE 1 II

MERCURY INFUSION POROSIMETRY AND GRAIN DENSITY POROSITY DATA

\begin{tabular}{|c|c|c|c|c|c|}
\hline Sample & $\begin{array}{l}\text { Porosity } \\
(>0.1 \mu \mathrm{m})\end{array}$ & $\begin{array}{c}\mathrm{Bu}^{3} \mathrm{k} \\
\text { Density } \\
\left(\mathrm{g} / \mathrm{cm}^{3}\right)\end{array}$ & $\begin{array}{c}\text { Grain } \\
\text { Density } \\
\left(\mathrm{g} / \mathrm{cm}^{3}\right) \\
\end{array}$ & Method $^{a}$ & Porosity \\
\hline$H F-23^{b}$ & 0.100 & i. 46 & $\cdots$ & -- & -- \\
\hline $\begin{array}{l}\text { U12G-RNM9 } \\
(5.9 \text { to } 6.4 \mathrm{ft})\end{array}$ & 0.147 & 1.48 & $\begin{array}{l}2.20 \\
2.21\end{array}$ & $\begin{array}{l}K \\
W\end{array}$ & 0.33 \\
\hline $\begin{array}{l}\text { U12G-RNM9 } \\
(16.2 \text { to } 17.5 \mathrm{ft})\end{array}$ & 0.225 & 1.31 & $\begin{array}{l}2.20 \\
2.21\end{array}$ & $\begin{array}{l}K \\
W\end{array}$ & 0.40 \\
\hline
\end{tabular}

\footnotetext{
$a_{W}$ indicates grain density by water displacement. $K$ indicates grain density by kerosene displacement.

brom the tunnel wall of the HF-23 drift in G-Tunnel near the RNM9 hole.
} 
by the pycnometer technique described in Procedure ASTM D 854-58 (Ref. 2). Two wetting fluids were used: water and kerosene. The results with the two fluids were comparable, as shown in Table III. The sample porosities calculated from the bulk volume measurement are given in the final column of Table III. These values are in the same range as those given in Table II. The pore space in the samples that arises from pore diameters $<0.1 \mu \mathrm{m}$ results in mercury infusion porosimeter measurements that are significantly smaller than the grain density measurements.

Diffusion coefficients were measured for the diffusion of bromide or iodide ions through discs of Tunnel Bed tuffs. The samples were $2.54 \mathrm{~cm}$ in diameter and $0.635 \mathrm{~cm}$ thick. The ions for these measurements were in solution in tuff-treated Wel1 J-13 water (see Sec. III.A). The results of the diffusion coefficient measurements are given in Table IV. The total porosity, median pore diameter, and $\alpha / \tau^{2}$ data given in Table IV are for purposes of correlation with the effective diffusion coefficients. Although the median pore diameter measurements are too few to merit a definitive statement about correlation, there appears to be no correlation of the effective diffusion coefficients with total porosity, but the effective diffusion coefficients do show a trend similar to $\alpha / \tau^{2}$. The relationship between $\alpha / \tau^{2}$, which is called the constrictivitytortuosity parameter, and the effective diffusion coefficient is given by the equation derived from L. K. Porter et al. ${ }^{3}$

$$
\frac{\alpha}{\tau^{2}}=\frac{\mathrm{D}_{\mathrm{e}}}{\mathrm{D}_{\mathrm{o}} \emptyset_{\mathrm{T}}} \text {, }
$$

in which

$D_{e}$ is the effective diffusion coefficient,

$D_{0}$ is the aqueous diffusion coefficient,

$\emptyset_{\mathrm{T}}$ is the total porosity, and

$\tau$ is the same as $L_{e} / L$ in Ref. 3 .

Additional data are required before definite statements about correlative relationships can be made. 
TABLE IV

EFFECTIVE DIFFUSION COEFFICIENTS

\begin{tabular}{lccccr}
\multicolumn{1}{c}{ Sample } & $\begin{array}{c}\text { Diffusion } \\
\text { Species }\end{array}$ & $\begin{array}{c}\text { Effective } \\
\text { Diffusion } \\
\text { Coefficient } \\
\left(10^{-7} \mathrm{~cm}^{2} / \mathrm{s}\right)\end{array}$ & $\begin{array}{c}\text { Total } \\
\text { Porosity } \\
(\Phi)\end{array}$ & $\begin{array}{c}\text { Median Pore } \\
\text { Diameter } \\
(\mu \mathrm{m})\end{array}$ & $\frac{\alpha / \tau^{2}}{\mathrm{Br}^{-}}$ \\
$\begin{array}{l}\mathrm{U} 12 \mathrm{G}-\mathrm{RNM9} \\
0.8 \text { to } 1.0 \mathrm{ft}\end{array}$ & $4.71 \pm 0.11$ & 0.35 & -- & 0.08 \\
$\begin{array}{l}\mathrm{U} 12 \mathrm{G}-\mathrm{RNM9} \\
16.2 \text { to } 17.5 \mathrm{ft}\end{array}$ & $\mathrm{I}^{-}$ & $10.8 \pm 0.03$ & 0.40 & 0.57 & 0.16 \\
$\mathrm{U} 12 \mathrm{G}-\mathrm{RNM} 9$ & $\mathrm{Br}^{-}$ & $11.3 \pm 0.02$ & 0.33 & 0.61 & 0.21
\end{tabular}

\section{WATER PREPARATION AND CHARACTERIZATION}

Water to be used both in G-Tunnel field experiments and in laboratory measurements of fracture"flow characteristics with Tunnel Bed tuff should have a composition similiar to that of water equilibrated with the tuff. Otherwise, the water composition will vary during the course of an experiment through interactions with the tuff. These interactions, in the form of dissolution and precipitation reactions, may give rise to misleading interpretations of the experimental results. The investigations described here were undertaken to obtain a supply of water with a composition like that of water equilibrated with Tunnel Bed 5 tuff.

\section{A. Selection of Water and Rock Sources}

Water samples were collected from two seeps that occur in the EV-5 area of G Tunnel, near the top of the Tunnel Bed tuff formation, and from two NTS wells (Wel1 8 and Well J-13) that are located in tuffaceous media. The waters from the seeps and from Wel1 J-13 were filtered through $0.05-\mu \mathrm{m}$ Nuclepore polycarbonate filters and analyzed with a plasma-source emission spectrometer. The results are shown in Table $V$, with US Geological Survey (USGS) analysis results for Wel1 8 water. 4

Wel1 8 and Well J-13 waters were contacted for 2-week and 4-week times with fracture-fill material and Tunnel Bed tuff to determine what the composition of water might be at equilibrium with these G-Tunnel materials. These samples were 
filtered through $0.05-\mu \mathrm{m}$ Nuclepore filters and analyzed like the water samples described above. The proportions of rock and water were varied, as shown in Table V.

The results of this work indicate that the water from the EV-5 seeps does not appear to be in equilibrium with the Tunnel Bed tuff. Previously published work ${ }^{5}$ showed the striking change in water composition with depth in the peralkaline tuffs of the Miocene tunnel beds. The sodium concentration in the water increased with depth, and the calcium concentration decreased with depth. Changes like these in water composition apparently require a greater residence time at a given depth than the seep water received for equilibrium to be established. The final composition of water contacted with the fracture fill or tuff matrix in various proportions appears to depend very little or not at all on the initial water source, the rock type, and the relative proportions of rock and water. Consequently, We1l J-13 water and matrix rock will be used to prepare water for these studies, because of their ready availability. Water-torock proportions of $10: 1$ will be used.

\section{B. Filtration Effects}

Unusually high concentrations of iron and silicon were observed in water that was contacted with Tunnel Bed tuff, then filtered through $0.45-\mu m$ Millipore HA filters before analysis. Consequently, the water was passed through filters with smaller diameter pores to determine whether the analysis results were a function of the pore size. The results of filtering the treated water through

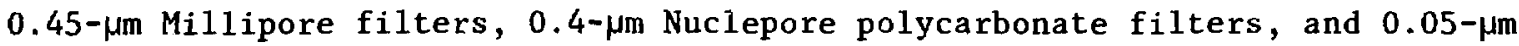
Nuclepore polycarbonate filters are listed in Table VI. Filtration of the water through 0.05- $\mu \mathrm{m}$ Nuclepore filters was chosen for all further work because the decrease of element concentrations with pore size (as shown in Table VI) indicates that fine particles of the tuff may be passing through the larger filters. The Tunnel Bed tuff exhibits a much greater tendency to produce small particles and colloids than any of the other NTS tuffs studied to date at Los Alamos.

The concentration of $\mathrm{Fe}(\mathrm{II})$ in Well J-13 water was determined in a spectrophotometric procedure that uses 4,7-dipheny1-1,10-phenanthroline as the detection agent. The Well J-13 water had been contacted with Tunnel Bed tuff in a controlled atmosphere of nitrogen in which oxygen was $<0.2 \mathrm{ppm}$ and carbon dioxide was $<20 \mathrm{ppm}$. The water was filtered through a $0.05-\mu \mathrm{m}$ Nuclepore filier. 
TABLE V

WATER COMPOSITIONS

\begin{tabular}{|c|c|c|c|c|c|c|c|c|c|c|c|}
\hline \multirow[b]{2}{*}{ Water } & \multicolumn{11}{|c|}{$\begin{array}{c}\text { Concentration } \\
(\mathrm{mg} / \mathrm{l})\end{array}$} \\
\hline & $\mathrm{Mg}$ & $\mathrm{Mn}$ & $\underline{\mathrm{Si}}$ & $\mathrm{Fe}$ & $\mathrm{Ba}$ & $\mathrm{V}$ & $\mathrm{Ti}$ & $\mathrm{Ca}$ & $\mathrm{K}$ & $\mathrm{Al}$ & $\mathrm{Na}$ \\
\hline \multirow{2}{*}{\multicolumn{12}{|c|}{ Untreated Water }} \\
\hline & & & & & & & & & & & \\
\hline $\operatorname{seep}_{b}^{a}$ & 0.14 & 0.09 & 30 & 1.0 & 0.002 & 0.001 & 0.13 & 0.81 & 3.8 & 0.4 & 34 \\
\hline seep & 0.24 & 0.10 & 28 & 2.4 & 0.002 & 0.001 & 0.18 & 0.38 & 2.7 & 1.4 & 42 \\
\hline Wel1 J-13 & 2.4 & 0.12 & 31 & 0.02 & 0.02 & 0.017 & -- & 12.6 & 9.2 & 0.05 & 59 \\
\hline Well $8^{c}$ & 1.1 & $<0.01$ & 27 & $<0.01$ & - & -- & -- & 8.3 & 3.6 & $<0.1$ & 31 \\
\hline
\end{tabular}

Water $\underline{\text { Rock }}^{\mathrm{e}} \quad \begin{aligned} & \text { Water:Rock } \\ & \text { Proportions }\end{aligned}$

Treated Water

\begin{tabular}{|c|c|c|c|c|c|c|c|c|c|c|c|c|c|}
\hline Well 8 & $\mathrm{ff}$ & $20: 1$ & 0.046 & 0.089 & 29 & 1.8 & 0.020 & 0.01 & 0.11 & 0.34 & 6.0 & 0.041 & 59 \\
\hline " & $\mathrm{ff}$ & $10: 1$ & 0.032 & 0.078 & 32 & 1.6 & 0.005 & 0.01 & 0.10 & 0.29 & 4.5 & 0.032 & 64 \\
\hline$"$ & $\mathrm{ff}$ & $10: 1$ & 0.024 & 0.137 & 34 & 3.5 & 0.023 & 0.012 & 0.28 & 0.60 & 6.1 & 0.030 & 90 \\
\hline Well 8 & $\mathbf{m}$ & $10: 1$ & 0.030 & 0.055 & 30 & 0.16 & 0.02 & 0.012 & 0.005 & 0.30 & 4.8 & 0.1 & 61 \\
\hline & $\mathbf{m}$ & $5: 1$ & 0.03 & 0.055 & 30 & 0.26 & 0.02 & 0.010 & 0.01 & 0.25 & 5.4 & 0.1 & 68 \\
\hline
\end{tabular}

\footnotetext{
${ }^{a}$ Middle of incline near EV-5

${ }^{b}$ Lower incline near EV-5

CFrom Ref. 4.

Average value for 2 -week and 4-week contacts in air. Filtered through $0.05-\mu m$ Nuclepore filters.

$e_{f f}=H F-23$ fracture fill; $m=H F-23$ matrix.
} 
TABLE VI

EFFECT OF FILTRATION ON WATER COMPOSITION ${ }^{a}$

\begin{tabular}{|c|c|c|c|}
\hline \multirow[b]{2}{*}{ Element } & \multicolumn{3}{|c|}{$\begin{array}{c}\text { Concentration } \\
(\mathrm{mg} / \mathrm{l})\end{array}$} \\
\hline & $0.45-\mu \mathrm{m} \mathrm{M}^{\mathrm{b}}$ & $0.40-\mu \mathrm{m} \mathrm{N}^{\mathrm{C}}$ & $\underline{0.05-\mu \mathrm{m} \mathrm{N}} \mathrm{N}^{\mathrm{C}}$ \\
\hline $\mathrm{Mg}$ & 4.0 & 0.11 & 0.08 \\
\hline $\mathrm{Mn}$ & 7.4 & 0.058 & 0.021 \\
\hline $\mathrm{Si}$ & 219 & 28.3 & 27.1 \\
\hline $\mathrm{Fe}$ & 82.0 & 1.5 & 0.6 \\
\hline $\mathrm{Sr}$ & 0.045 & 0.000 & 0.001 \\
\hline $\mathrm{Ba}$ & 9.0 & 0.05 & 0.12 \\
\hline V & 0.17 & 0.005 & 0.008 \\
\hline $\mathrm{Ti}$ & 14. & 0.09 & 0.00 \\
\hline $\mathrm{Ca}$ & 5.4 & 0.70 & 0.56 \\
\hline $\mathrm{Li}$ & 80 & 0.059 & 0.050 \\
\hline $\mathbf{K}$ & 30 & 4.5 & 4.9 \\
\hline $\mathrm{AI}$ & 39. & 0.7 & 0.009 \\
\hline $\mathrm{Na}$ & 102.5 & 94.1 & 89.0 \\
\hline $\begin{array}{r}{ }_{\mathrm{J}-13} \\
\text { cent } \\
\mathrm{b}_{\mathrm{Mil1}}\end{array}$ & $\begin{array}{l}\text { er contacte } \\
\text { efore succe } \\
\text { membrane. }\end{array}$ & $\begin{array}{l}\text { trix tuff } \\
\text { trations. }\end{array}$ & is and \\
\hline
\end{tabular}

The Fe(II) concentration was $<0.01 \mathrm{mg} / \mathrm{l}$. Therefore, the iron listed in Table II is assumed to be iron either in solution as Fe(III) or associated with particles $<0.05 \mu \mathrm{m}$.

\section{Effects of Contact Time}

An apparatus was constructed for contacting Well $\mathrm{J}-13$ water in $\sim 200-\ell$ batches with $\sim 20 \mathrm{~kg}$ of crushed Tunnel Bed tuff. The apparatus consists of a 55-gal,, polyethylene-lined barrel with an inverted, perforated polyethylene funnel placed inside the barrel. The tuff was placed over the funnel. The Well J-13 water was put into the barrel and circulated with a peristaltic pump, which forced the water down through the funnel, then up through the tuff. 
After 28 days of contact, the water was passed through a $0.05-\mu m$ Nuclepore filter, a process that required three 8-hour shifts; then it was transferred to a second barrel containing $\sim 20 \mathrm{~kg}$ of fresh crushed tuff. The water was contacted with the second batch of tuff for 24 days. Small aliquots of water were removed at intervals throughout both contact periods to measure water composition. Each aliquot was filtered through a 0.05- $\mathrm{m}$ Nuclepore filter. A portion of each aliquot was acidified to determine cations and silicon by emission spectroscopy. The results of these measurements are given in Table VII. The unacidified portion of each aliquot was used to measure anions by ion chromatography and acidimetric titration. These results are given in Table VIII. The composition of untreated Wel1 J-13 water is given in each of these two tables for comparison with the other results. The data in the tables indicate that a 7-day contact of Well J-13 water with a single batch of tuff is sufficient to prepare water for use in this experimental program.

The $\mathrm{pH}$ of the Well J-13 water varied $<0.08$ during the treatment with tuff that is described above. The average $\mathrm{pH}$ value is $8.32 \pm 0.03$.

One measure of the quality of the water compositicn data, which are shown in Tables VII and VIII, is provided by : uparing the cation concentrations with the anion concentrations. The values for the untreated Well $\mathrm{J}-13$ water are $2.85 \mathrm{meq} / \ell$ for cations and $3.17 \mathrm{meq} / \ell$ for anions. The average experimental normalities of the tuff-treated water are $3.17 \mathrm{meq} / \mathrm{l}$ for cations and $2.86 \mathrm{meq} / \mathrm{l}$ for anions. The differences of normalities for cations and anions, 10 and $11 \%$ for the untreated and treated water, respectively, are within the range of the 1 to 15\% differences typically observed by the USGS in water analyses (see, for example, Ref.6).

D. Effects of Standing Time and Acidification on Cation Analysis

Experiments were performed to investigate whether the composition of tufftreated water changes with standing time and whether the addition of acid to the filtered water results in increased stabilization. We11 J-13 water that had been contacted with Tunnel Bed tuff and filtered through 0.05- $\mu \mathrm{m}$ Nuclepore filters was analyzed for cations soon after filtration and again $\sim 4$ months later. Some of the filtered water samples were acidified to $0.1 \mathrm{M} \mathrm{HNO}_{3}$ and analyzed at the same two times. The results are shown in Table IX; the compositons of the waters do not vary significantly with standing time, and acidification does not affect the results significantly. 
TABLE VII

ANALYSES OF WELL $J-13$ WATER TREATED WITH TUNNEL BED TUFF

\begin{tabular}{|c|c|c|c|c|c|c|c|c|c|c|c|c|c|}
\hline \multirow[b]{2}{*}{$\begin{array}{l}\text { Uncontacted }^{a, b} \\
\text { Water }\end{array}$} & \multicolumn{13}{|c|}{$\begin{array}{c}\text { Concentration } \\
(\mathrm{mg} / \mathrm{l})\end{array}$} \\
\hline & $\frac{\mathrm{Hg}}{1.8}$ & $\frac{\mathrm{Mn}}{0.010}$ & $\frac{\mathrm{Fe}}{0.018}$ & $\frac{S r}{0.04}$ & $\frac{3 a}{0.001}$ & $\frac{v}{0.016}$ & $\frac{\mathrm{Ti}}{0.013}$ & $\frac{\overline{L i}}{0.066}$ & $\frac{k}{5}$ & $\frac{\mathrm{A} 1}{0.106}$ & $\frac{N a}{45}$ & $\frac{\mathrm{Si}}{25}$ & $\mathrm{Ca}$ \\
\hline \multicolumn{14}{|l|}{ 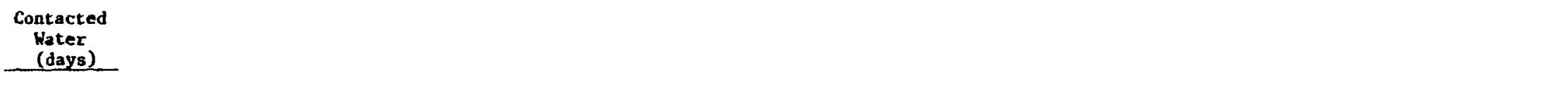 } \\
\hline \multicolumn{14}{|c|}{ First contact } \\
\hline $\begin{array}{c}3^{b} \\
7 \\
10 \\
21 \\
28\end{array}$ & $\begin{array}{l}0.031 \\
0.044 \\
0.042 \\
0.031 \\
0.035\end{array}$ & $\begin{array}{l}0.012 \\
0.017 \\
0.019 \\
0.021 \\
0.026\end{array}$ & $\begin{array}{l}0.13 \\
0.21 \\
0.20 \\
0.19 \\
0.19\end{array}$ & $\begin{array}{l}0.001 \\
0.002 \\
0.002 \\
0.002 \\
0.001\end{array}$ & $\begin{array}{l}0.002 \\
0.003 \\
0.004 \\
0.004 \\
0.001\end{array}$ & $\begin{array}{l}0.010 \\
0.010 \\
0.020 \\
0.022 \\
0.015\end{array}$ & $\begin{array}{l}0.008 \\
0.008 \\
0.015 \\
0.012 \\
0.013\end{array}$ & $\begin{array}{l}0.035 \\
0.056 \\
0.053 \\
0.058 \\
0.041\end{array}$ & $\begin{array}{l}2.03 \\
2.59 \\
2.55 \\
2.72 \\
2.46\end{array}$ & $\begin{array}{l}0.040 \\
0.057 \\
0.056 \\
0.046 \\
0.043\end{array}$ & $\begin{array}{l}58.2 \\
69.1 \\
70.1 \\
70.5 \\
70.9\end{array}$ & $\begin{array}{l}26.0 \\
30.0 \\
29.5 \\
28.8 \\
29.6\end{array}$ & $\begin{array}{l}0.47 \\
0.68 \\
0.70 \\
0.59 \\
0.64\end{array}$ \\
\hline \multicolumn{14}{|c|}{ Second contact } \\
\hline $\begin{array}{r}3 \\
7 \\
19 \\
24\end{array}$ & $\begin{array}{l}0.029 \\
0.031 \\
0.024 \\
0.028\end{array}$ & $\begin{array}{l}0.007 \\
0.005 \\
0.005 \\
0.005\end{array}$ & $\begin{array}{l}0.07 \\
0.03 \\
0.05 \\
0.05\end{array}$ & $\begin{array}{l}0.001 \\
0.000 \\
0.001 \\
0.000\end{array}$ & $\begin{array}{l}0.001 \\
0.000 \\
0.001 \\
0.001\end{array}$ & $\begin{array}{l}0.012 \\
0.007 \\
0.013 \\
0.014\end{array}$ & $\begin{array}{l}0.007 \\
0.006 \\
0.020 \\
0.019\end{array}$ & $\begin{array}{l}0.020 \\
0.022 \\
0.044 \\
0.040\end{array}$ & $\begin{array}{l}2.52 \\
2.43 \\
2.42 \\
2.37\end{array}$ & $\begin{array}{l}0.031 \\
0.031 \\
0.025 \\
0.026\end{array}$ & $\begin{array}{l}70.6 \\
71.4 \\
70.5 \\
70.5\end{array}$ & $\begin{array}{l}28.7 \\
28.8 \\
29.0 \\
27.8\end{array}$ & $\begin{array}{l}0.66 \\
0.63 \\
0.53 \\
0.68\end{array}$ \\
\hline Hean & 0.033 & 0.013 & 0.12 & 0.001 & 0.002 & 0.014 & 0.012 & 0.042 & 2.51 & 0.039 & 70.4 & 28.9 & 0.64 \\
\hline $\begin{array}{l}\text { Std. deviation } \\
\text { of the sample }\end{array}$ & 0.007 & 0.009 & 0.08 & 0.001 & 0.002 & 0.005 & 0.005 & 0.014 & 0.11 & 0.013 & 0.7 & 0.9 & 0.06 \\
\hline $\begin{array}{l}\text { Typical std. } \\
\text { dev. of single } \\
\text { analysis }\end{array}$ & 0.001 & 0.002 & 0.01 & - & 0.001 & 0.005 & 0.003 & 0.010 & 0.05 & 0.001 & 1.5 & 0.3 & 0.1 \\
\hline $\begin{array}{l}\text { Limit of } \\
\text { detection }\end{array}$ & 0.001 & 0.002 & 0.02 & -- & 0.0005 & 0.01 & 0.002 & 0.016 & 0.05 & 0.004 & 3.0 & 0.05 & 0.006 \\
\hline $\begin{array}{l}\text { Hean concen- } \\
\text { tration }(\omega M)\end{array}$ & $1.36 \times 10^{-3}$ & $2.4 \times 10^{-4}$ & $2.2 \times 10^{-3}$ & $1 \times 10^{-5}$ & $1 \times 10^{-5}$ & $2.8 \times 10^{-4}$ & $2.6 \times 10^{-4}$ & $6.0 \times 10^{-3}$ & $6.4 \times 10^{-2}$ & $1.5 \times 10^{-3}$ & 3.06 & 1.03 & $1.59 \times 10^{-2}$ \\
\hline
\end{tabular}

ater from well $J-13$, not contacted with Tunnel Bed tuff (listed for comparison).

boitted in wean.

$C_{A}$ measure of run-to-run analytical precision, assuming that the members in the mean belong to the same sanplin.

Within-run analytical precision based on three repeat measurements on a sample. 
TABLE VIII

COMFOSITION OF WELL J-13 WATER TREATED WITH TUNNEL BED TUFF AND MEASURED BY ANION CHROMATOGRAPHY AND ACIDIMETRIC TITRATION

\begin{tabular}{|c|c|c|c|c|c|}
\hline & \multicolumn{4}{|c|}{$\begin{array}{r}\text { Concentration } \\
(\mathrm{mg} / 2)\end{array}$} & \multirow[b]{2}{*}{$\mathrm{HCO}_{3}$} \\
\hline & $F$ & $\mathrm{Cl}$ & $\mathrm{NO}_{3}$ & $\mathrm{SO}_{4}$ & \\
\hline Uncontacted Water ${ }^{a}$ & 2.8 & 9.4 & 8.1 & 23 & 131 \\
\hline \multicolumn{6}{|l|}{$\begin{array}{c}\text { Cuntacted Water } \\
\text { (days) }\end{array}$} \\
\hline \multicolumn{6}{|l|}{ First contact } \\
\hline 10 & 2.5 & 9.2 & 5.9 & 17.1 & 126 \\
\hline 28 & 2.4 & 9.1 & 6.4 & 17.6 & 120 \\
\hline \multicolumn{6}{|l|}{ Second contact } \\
\hline 3 & 2.3 & 9.6 & 6.4 & 18.1 & 121 \\
\hline 7 & 2.3 & 9.7 & 6.0 & 18.2 & 122 \\
\hline Mean & 2.38 & 9.4 & 6.2 & 17.8 & 122 \\
\hline $\begin{array}{l}\text { Std. dev. of } \\
\text { the sample }\end{array}$ & 0.10 & 0.3 & 0.3 & 0.5 & 3 \\
\hline $\begin{array}{l}\text { Mean concen- } \\
\text { tration (mM) }\end{array}$ & 0.125 & 0.265 & 0.100 & 0.185 & $\therefore 00$ \\
\hline
\end{tabular}

\section{E. Tritium Content of Water in Tuff from Core U12G-RNM9}

Portions of tuff were removed from opposite ends of core U12G-RNM9, 1.0 to $3.4 \mathrm{ft}$, which had been stored in a plastic bag that was wrapped with tape. The water was removed from the Tunnel Bed tuff by heating and condensing. The measured tritium concentration was 1.05 and $3.03 \mathrm{nCi} / \mathrm{ml}$ at depths of 3.4 and $1.0 \mathrm{ft}$ from the tunnel wall, respectively.

IV. BATCH SORPTION EXPERIMENTS

A. Crushed-Tuff Matrix

Experiments were performed to measure the sorption of radioactive tracers onto crushed Tunnel Bed tuff from tuff-treated Well J-13 water. The Tunnel Bed 
TABLE IX

OBSERVED VARIATION IN WATER COMPOSITION WITH STANDING TIME

$$
\text { AND ACID STABILIZATION }{ }^{\mathbf{a}}
$$

\begin{tabular}{|c|c|c|c|c|c|c|c|c|c|c|c|c|c|c|}
\hline $\begin{array}{l}0.1 \mathrm{~N} \mathrm{HNO}_{3} \\
\text { Treatment } \\
\end{array}$ & $\begin{array}{c}\text { Date } \\
\text { Analyzed }\end{array}$ & $\mathrm{Mg}$ & Mn & Si & $\mathrm{Fe}$ & $\mathrm{Sr}$ & $\mathrm{Ba}$ & $\mathrm{V}$ & $\mathrm{Ti}$ & $\mathrm{Ca}$ & $\mathrm{Li}$ & K & Al & $\mathrm{Na}$ \\
\hline none & $2-27-81$ & 0.064 & 0.046 & 26.9 & 0.604 & 0.002 & 0.028 & 0.008 & 0.003 & 0.678 & 0.045 & 6.22 & 0.234 & 94.0 \\
\hline none & $6-19-81$ & 0.103 & 0.024 & 30.6 & 0.852 & 0.005 & 0.005 & 0.012 & 0.034 & 0.961 & 0.045 & 3.96 & 0.346 & 92.4 \\
\hline acidified & $2-27-81$ & 0.095 & 0.049 & 31.0 & 0.354 & 0.005 & 0.107 & 0.010 & 0.006 & 1. 40 & 0.053 & 6.18 & 0.207 & 96.0 \\
\hline acidified & $6-19-81$ & 0.137 & 0.023 & 35.4 & 0.815 & 0.008 & 0.016 & 0.016 & 0.058 & 1.33 & 0.050 & 4.04 & 0.432 & 93.6 \\
\hline
\end{tabular}

${ }^{a}$ We11 j-13 water contacted with Tunnel Bed tuff and filtered through $0.05-\mu m$ Nuclepore filters. 
tuff came from G-Tunnel drift HF23, hole U12G-RNM9, 10.8 to $11.9 \mathrm{ft}$. The tuff was crushed to a particle size $<500 \mu \mathrm{m}$. The Well J-13 water was treated with Tunnel Bed tuff in the manner described in Sec. III, then filtered through $0.05-\mu m$ Nuclepore filters. Batches containing $20 \mathrm{~m} \ell$ water, $1 \mathrm{~g}$ crushed tuff, and appropriate tracers were shaken for 2- to 6-week periods under controlled atmosphere conditions (nitrogen with $<0.2 \mathrm{ppm}$ oxygen and $<20 \mathrm{ppm}$ carbon dioxide). The results of these batch sorption measurements, which were performed in duplicate, are repcited in Table $X$ in terms of a distribution ratio $R_{d}$; the distribution ratio is defined as the activity per gram of solid divided by the activity per milliliter of solution. The symbol $R_{d}$ is used for this work to indicate uncertainty concerning the achievement of equilibrium conditions during the experiment. When equilibrium conditions are known to occur or assumed to occur, as in theoretical Lreatments, the symbol $\mathrm{K}_{\mathrm{d}}$ is used for this ratio.

The crushea-tuff samples with the sorbed ${ }^{85} \mathrm{Sr},{ }^{137} \mathrm{Cs},{ }^{133} \mathrm{Ba}$, and ${ }^{152} \mathrm{Eu}$ tracers were contacted with new 20-ml aliquots of tuff-treated We11 J-13 water Lo measure desorption. Contact periods of 3 and 6 weeks were used for these measurements, which were done under controlled atmosphere conditions, as were the sorption measurements. The results are given in Table XI.

A comparison of the results in Tables $X$ and $X I$ indicates that the $R_{d}$ values for a given tracer approach an equilibrium value with time both in so:ption and in desorption experiments. The reproducibility of duplicate determinations is poor, particularly in the desorption measurements. These types of measurements have been performed at Los Alamos with tuffs from other sources. The reproducibility of results from duplicate determinations with Tunnel Bed tuff is poorer than for any of the other tuffs studied. This poor reproducibility may be related to the fine particles that are unique to this tuff.

\section{B. Crushed Fracture-Fill Material}

An experiment like those described in Sec. IV.A was performed to measure sorption onto material that had filled a naturally occurring fracture in Tunnel Bed tuff. This experiment was undertaken to determine whether fracture-fill material displayed radionuclide sorption characteristics that were significantly different from thc;: shown by the crushed-tuff matrix material used in the other batch experiments. 
TABLE $X$

AVERAGE $R_{d}$ VALUES FOR SORPTION OF RADIONUCLIDES ONTO TUNNEL BED TUFF

\begin{tabular}{|c|c|c|c|c|}
\hline Tracer & Valence & $\begin{array}{c}\text { Contact Time } \\
\text { (weeks) }\end{array}$ & $\begin{array}{c}\mathrm{R}_{\mathrm{d}} \\
(\mathrm{m} \ell / \mathrm{g})\end{array}$ & $\begin{array}{c}\text { Standard } \\
\text { Deviation } \\
\text { of Mean }\end{array}$ \\
\hline \multirow[t]{2}{*}{${ }^{22} \mathrm{Na}$} & $I$ & 2 & 180 & 11 \\
\hline & & 4 & 194 & 6 \\
\hline \multirow[t]{2}{*}{${ }^{54} \mathrm{Mn}$} & I I & 2 & 2050 & 330 \\
\hline & & 4 & 480 & 260 \\
\hline \multirow[t]{2}{*}{${ }^{75} \mathrm{Se}$} & IV & 2 & 1.9 & 0.5 \\
\hline & & 4 & 1.6 & 0.1 \\
\hline \multirow[t]{2}{*}{${ }^{85} \mathrm{Sr}$} & I I & 3 & 41000 & 2000 \\
\hline & & 6 & 48000 & 6000 \\
\hline${ }^{113} \mathrm{Sn}$ & II & 3 & 380 & 130 \\
\hline \multirow[t]{2}{*}{${ }^{137} \mathrm{Cs}$} & $I$ & 3 & 15600 & 400 \\
\hline & & 6 & 12000 & 1000 \\
\hline \multirow[t]{2}{*}{${ }^{133} \mathrm{Ba}$} & II & 3 & 6300 & 700 \\
\hline & & 6 & 4600 & 500 \\
\hline \multirow[t]{2}{*}{${ }^{152} \mathrm{Eu}$} & I I I & 3 & 590 & 40 \\
\hline & & $E$ & 510 & 100 \\
\hline
\end{tabular}

The fracture-fill material for this experiment lined a natural fracture that was observed in the "waxed and wrapped" core from U12G-RNM9, 7.1 to 8.1 ft. The fracture-fill material was pulverized by grinding the two faces of the core against each other, but it was not sieved. This batch sorption experiment was performed in a controlled atmosphere (nitrogen with $<0.2 \mathrm{ppm}$ oxygen and $<20 \mathrm{ppm}$ 
TABLE XI

AVERAGE $R_{d}$ VALUES FOR DESORPTION OF RADIONUCLIDES FROM TUNNEL BED TUFF

\begin{tabular}{|c|c|c|c|c|}
\hline Tracer & $\begin{array}{c}\text { Contact Time } \\
\text { (weeks) }\end{array}$ & $\begin{array}{c}R_{\mathrm{d}} \\
(\mathrm{m} \ell / \mathrm{g}) \\
\end{array}$ & $\begin{array}{c}\text { Stan } \\
\text { Devi } \\
\text { of } \\
\end{array}$ & $\begin{array}{l}\text { adard } \\
\text { iation } \\
\text { Mean }\end{array}$ \\
\hline${ }^{85} \mathrm{Sr}$ & 3 & 96000 & 8 & 000 \\
\hline & 6 & 51000 & 10 & 000 \\
\hline${ }^{133} \mathrm{Ba}$ & 3 & 19000 & 4 & 000 \\
\hline & 6 & 4400 & & 200 \\
\hline${ }^{137} \mathrm{Cs}$ & 3 & 25000 & 4 & 000 \\
\hline \multirow{3}{*}{${ }^{152}$ Eu } & 6 & 13000 & 5 & 000 \\
\hline & 3 & 4100 & & 300 \\
\hline & 6 & 1600 & & 800 \\
\hline
\end{tabular}

carbon dioxide) with We1l J-13 water that had been treated with Tunnel Bed tuff and filtered through $0.05-\mu \mathrm{m}$ Nuclepore filters. The results are given in Table XII.

A comparison of the data in Table XII with those in Table X for the same tracers and contact times shows that the $R_{d}$ values for cesium and europium are in reasonable agreement, but the sorption of strontium onto crushed-tuff matrix yields $R_{d}$ values about 20 times those obtained with fracture-fill material, and the $R_{d}$ values for barium are two to four times greater for sorption onto fracture-fill material. The reasons for these observations are not known. One would expect from the data given in Table I that the sorption characteristics of crushed-tuff matrix and fracture-fill material would be about the same.

C. Wafers

Batch sorption measurements were performed with Tunnel Bed tuff in the form of wafers suspended from nylon lines in solutions containing radioactive tracers. The water containing the tracers was the customary Well J-13 water, which had been contacted with Tunnel Bed tuff and filtered through 0.05- $\mu \mathrm{m}$ filters. This batch sorption method was investigated to see if the resulting $R_{d}$ values might 


\section{TABLE XII}

SORPTION RATIOS FOR FRACTURE-FILL, SAMPLES ${ }^{\mathrm{a}}$

\begin{tabular}{|c|c|c|c|c|c|c|}
\hline \multirow{2}{*}{$\begin{array}{c}\begin{array}{c}\text { Time } \\
\text { (weeks) }\end{array} \\
\end{array}$} & \multicolumn{6}{|c|}{$\mathrm{R}_{\mathrm{d}}(\mathrm{ml} / \mathrm{g})$} \\
\hline & $\mathrm{Cs}$ & Sr & $\mathrm{Ba}$ & $\mathrm{Ce}$ & $\mathrm{Eu}$ & $\mathrm{Tc}$ \\
\hline 1 & $10400(3.7)$ & $1350(2.7)$ & $20000(5.3)$ & $240(5.9)$ & $320(5.4)$ & 0.0047 \\
\hline 1 & $2100(2.2)$ & $470(2.2)$ & $3900(2.0)$ & $230(4.2)$ & $280(3.3)$ & \\
\hline 3 & $13000(5.8)$ & $1800(3.9)$ & $21000(7.5)$ & $380(8.7)$ & $490(8.4)$ & 0.72 \\
\hline 3 & $15000(6.9)$ & $2500(4.4)$ & $26000(9.5)$ & $340(10.2)$ & $443(9.9)$ & 0.66 \\
\hline 4 & $16000(8.1)$ & $2300(5.9)$ & $7200(4.3)$ & $760(11.9)$ & $870(11.7)$ & 1.79 \\
\hline 4 & $13000(7.5)$ & $2200(5.8)$ & $7400(4.1)$ & $490(11.1)$ & $720(10.8)$ & 1.42 \\
\hline 6 & $8300(5.6)$ & $2400(6.2)$ & $7600(4.7)$ & $550(8.7)$ & $760(8.3)$ & \\
\hline 6 & $9800(5.4)$ & $1900(6.2)$ & $9700(5.3)$ & $670(8.4)$ & $1000(8.0)$ & \\
\hline
\end{tabular}

\footnotetext{
${ }^{a}$ The values in parentheses are the standard deviations (in per cent) for a single measurement of the $R_{d}$ values; they were obtained from the errors associated with the activity measurements and estimated uncertainties for the various parameters entering into the calculation. These estimated uncertainties were propagated using the rule of change of variables in a moment matrix, assuming independence of the variables.
} 
be more appropriate for predicting radionuclide transport in the case of a waste nuclide repository breach than would the $R_{d}$ valdes measured with crushedtuff matrix samples.

One set of experiments was performed to deternine the ef chects of different wafer thicknesses and different contact times. The wafers were prepared with matrix material from core U12G-RNM9, 16.2 to $17.5 \mathrm{ft}$. The thicknesses of these 13.5-mm-diam wafers varied from 5 to $9 \mathrm{~mm}$. Sorption measurements were performed in air with varying contact times (see Table XIII). The $R_{d}$ values in Table XIII are comparable in magnitude to those in Table XII, but the strontium $R_{d}$ values are much lower than those in Table $X$. There is no obvious correlation of wafer $R_{d}$ values with wafer thickness or time of contact.

A second set of wafers, $17 \mathrm{~mm}$ in diameter and $2 \pm 0.5 \mathrm{~mm}$ thick, was used to determine the amount of activity in a tracer solution that was sorbed onto the wafer as a function of contact time. The contact times varied from 10 seconds to 119 days. The wafers were soaked for 2 weeks in the customary tuff-treated and filtered Well J-13 water before the start of the sorption experiments. Then the wafers were suspended from Teflon thread in the tufftreated Well J-13 water that contained ${ }^{85} \mathrm{Sr},{ }^{137} \mathrm{Cs},{ }^{133} \mathrm{Ba}$, and ${ }^{152} \mathrm{Eu}$ tracers in one set of measurements and ${ }^{95} \mathrm{Tc}^{\mathrm{m}}$ or ${ }^{131} \mathrm{I}$ in ancther set. The results of the ${ }^{95} \mathrm{Tc}^{\mathrm{m}}$ and ${ }^{131} \mathrm{I}$ sorption measurements are given in Table XIV. If the ${ }^{95} \mathrm{TC}^{\mathrm{m}}$ had diffused into all the water remaining in the wafer after its 2 -week soak, $1.8 \%$ of the technetium should have been detected with the wafer. The datum for 916 hours in Table XIV shows that $1.3 \%$ of the total technetium activity was measured, which indicates that equilibrium was not reached by that time. The iodine sorption experiments were terminated after 777 hours, because the ${ }^{131}$ I had decayed to $\sim 6 \%$ of its initial activity. This sma11 amount of activity resulted in poor counting statistics. The observed iodine sorption of $1.51 \%$ at 777 hours is too : yor a value to be significantly different from $1.27 \%$, which is the ${ }^{131} \mathrm{I}$ equilibrium value that would be observed if the ${ }^{131} \mathrm{I}$ had diffused into all the water in the wafer after its 2-week soak. One can conclude from these measurements that there is no evidence for the sorption of ${ }^{95} \mathrm{Tc}^{\mathrm{m}}$ or ${ }^{131} \mathrm{I}$ ions onto the Tunnel Bed tuff wafers.

The results of the measurements of cation sorption onto the Tunnel Bed tuff wafers are given in Tables XV and XVI. The rapid sorption of strontium, cesium, and barium onto these wafers (shown in Table XV) is what one might expect for this zeolitized tuff. The $R_{d}$ values for wafer sorption times of 
TABLE XIII

SORPTION RATIOS FOR WAFERS

\begin{tabular}{|c|c|}
\hline $\begin{array}{c}\text { Contact } \\
\text { Time } \\
\text { (days) }\end{array}$ & $\begin{array}{l}\text { Thickness } \\
\text { (mm) }\end{array}$ \\
\hline 6 & 6.3 \\
\hline 12 & 5.6 \\
\hline 12 & 8.7 \\
\hline 27 & 8.3 \\
\hline
\end{tabular}

\begin{tabular}{|c|c|c|c|c|}
\hline $\mathrm{Sr}$ & $\mathrm{Cs}$ & $\mathrm{Ba}$ & $\mathrm{Ce}$ & $\overline{\text { Eu }}$ \\
\hline $370(2.2)^{\mathrm{a}}$ & $5500(3.2)$ & $9600(3.9)$ & $140(5.3)$ & $140(4.7)$ \\
\hline $430(2.1)$ & $7700(3.4)$ & $14000(4.3)$ & $280(5.5)$ & $270(4.8)$ \\
\hline $1300(3.3)$ & $10000(5.2)$ & $25000(10.9)$ & $130(7.8)$ & $150(7.4)$ \\
\hline $240(2.2)$ & $5200(3.4)$ & $11000(5.2)$ & $330(5.5)$ & $310(4.9)$ \\
\hline
\end{tabular}

${ }^{a}$ The values in parentheses are the standard deviations (in per cent) for a single measurement of the $R$ values; they were obtained from the errors associated with the activity measurements and estimated uncertainties for the various parameters entering into the calculation. These estimated uncercainties were propagated using the rule of change of variables in a moment matrix, assuming independence of the variables. 


\begin{tabular}{|c|c|c|c|}
\hline $\begin{array}{c}\text { Time } \\
\text { (hours) }\end{array}$ & ${ }^{95} \mathrm{Tc}^{\mathrm{m}}$ & $\begin{array}{c}\text { Time } \\
\text { (hours) }\end{array}$ & ${ }^{131} \mathrm{I}$ \\
\hline 0.5 & $0.56(0.05)^{a}$ & 0.5 & $0.60(0.02)$ \\
\hline 1.5 & $0.86(0.04)$ & 1.4 & $0.82(0.01)$ \\
\hline 4.0 & $0.98 \quad(0.02)$ & 18 & $0.99(0.01)$ \\
\hline 8.0 & $1.01(0.02)$ & 44 & $1.03(0.01)$ \\
\hline 80 & $1.11(0.01)$ & 164 & $1.05(0.01)$ \\
\hline 120 & $1.14(0.02)$ & 349 & $1.14(.01)$ \\
\hline 258.5 & $1.14(0.01)$ & 541 & $1.21(0.01)$ \\
\hline 408 & $1.18(0.02)$ & 777 & 1.51 \\
\hline 916 & $1.26(0.02)$ & & \\
\hline
\end{tabular}

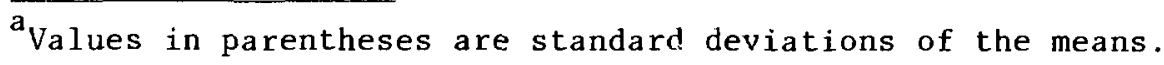

22 to 2850 hours are shown in Table XVI. When the data in Table XVI are compared with those in Table XIII, one can note that for similar sorpcion times, the strontium sorption in Table XVI is ten times greater than that shown in Table XIII. The cesium and barium data in Table XVI are factors of 2 to 6 lower than those in Table XIII, but the europium data in the two tables are similar. The data in Table XVI, like the other data, show no obvious correlation of $R_{d}$ with contact time or sample size, although at the longer contact times in Table XVI, there does seem to be a decrease in the $\mathrm{R}_{\mathrm{d}}$ value with an increase in sample size. The reasons for the differences in $R_{d}$ values between Tables XVI and XIII are not known.

\section{COLUMN SORPTION STUDIES}

\section{A. Crushed Fracture-Fill Column}

The sorption characteristics of ${ }^{85} \mathrm{Sr},{ }^{95} \mathrm{Tc}$, ${ }^{137} \mathrm{Cs},{ }^{133} \mathrm{Ba}$, and ${ }^{152}$ Eu were studied in an experiment in which the tracers were loaded in a small spike onto a column of crushed Tunnel Bed tuff material, then eluted with tuff-treated Well J-13 water. The column length is $5.0 \mathrm{~cm}$, the diameter is $0.5 \mathrm{~cm}$, and 
TABLE XV

CATION SORPTION DATA FOR TUNNEL BED TUFF WAFERS

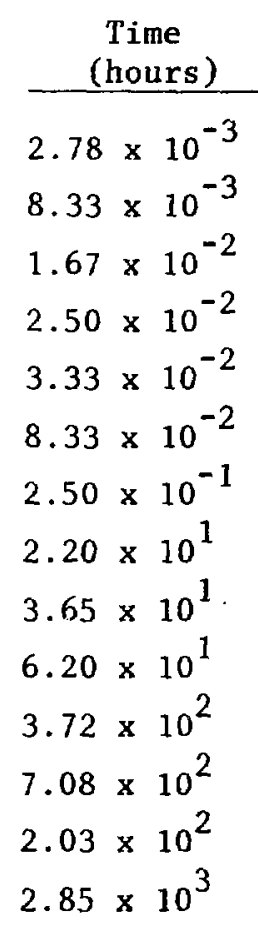

Total Activity Sorbed ${ }^{a}$

(\%)

\begin{tabular}{llll}
\hline $\mathrm{Sr}$ & $\mathrm{Cs}$ & $\mathrm{Ba}$ & $\mathrm{Eu}$ \\
\cline { 2 - 2 } 0.75 & 1.22 & 0.75 & 0 \\
2.40 & 3.92 & 2.15 & 0.44 \\
4.14 & 7.13 & 3.82 & 1.52 \\
6.46 & 11.0 & 5.81 & 2.57 \\
8.63 & 14.6 & 7.14 & 3.08 \\
13.3 & 23.0 & 11.5 & 5.16 \\
34.3 & 53.7 & 25.5 & 9.62 \\
99.5 & 99.0 & 97.8 & 72.6 \\
99.2 & 99.0 & 95.6 & 79.9 \\
99.6 & 99.1 & 97.8 & 70.9 \\
99.8 & 99.1 & 99.0 & 93.6 \\
99.9 & 99.3 & 99.4 & 94.0 \\
99.9 & 99.2 & 99.2 & 96.1 \\
99.9 & 99.2 & 99.2 & 96.8
\end{tabular}

The per cent of activity sorbed from $2.78 \times 10^{-3}$ to $2.5 \times 10^{-1}$ hours
was calculated by comparing the activity on the wafer with the total
activity added. The remaining values were calculated from the activity
remaining in solution compared to the original activity in solution.

the volume is $0.982 \mathrm{~cm}^{3}$. The material used in this column was fracture-fill material (described in Sec. IV) that was crushed to the range of 38 to $106 \mu \mathrm{m}$. The measured free-column volume was $0.699 \mathrm{~m} \ell$ with ${ }^{131} \mathrm{I}$ and $0.689 \mathrm{~m} \ell$ with tritiated water; both tracers were added to Well $\mathrm{J}-13$ water that had been treated with Tunnel Bed tuff and filtered through 0.05- $\mu \mathrm{m}$ Nuclepore filters. The density of the fracture-fill material in the column was $0.91 \mathrm{~g} / \mathrm{cm}^{3}$, and the porosity was 0.71 . 
TABLE XVI

SORPTION RATIOS FOR TUNNEL BED TUFF WAFERS

\begin{tabular}{|c|c|c|c|c|c|}
\hline \multirow{2}{*}{$\begin{array}{l}\text { Wafer } \\
(\mathrm{g})\end{array}$} & \multirow{2}{*}{$\begin{array}{l}\text { Time } \\
\text { (hours) }\end{array}$} & \multicolumn{4}{|c|}{$R_{\mathrm{d}}(\mathrm{m} \ell / \mathrm{g})$} \\
\hline & & $\mathrm{Sr}$ & $\mathrm{Cs}$ & $\mathrm{Ba}$ & $\mathrm{Eu}$ \\
\hline 1.34 & 22 & 3500 & 1900 & 440 & 90 \\
\hline 1.37 & & 4200 & & 500 & 31 \\
\hline 1.41 & & 3600 & 2300 & 470 & 45 \\
\hline 0.97 & 36.5 & 2700 & 2600 & 300 & 130 \\
\hline 1.41 & & 3000 & 2000 & 450 & 42 \\
\hline 1.78 & & 2500 & 1900 & 360 & 84 \\
\hline 1.11 & 62 & 4900 & 2000 & 710 & 42 \\
\hline 0.97 & 372 & 13000 & & 1800 & 360 \\
\hline 1.41 & & 8300 & & 3400 & 190 \\
\hline 1.78 & & 9600 & 2800 & 2400 & 320 \\
\hline 1.34 & 708 & 13000 & & 1900 & 260 \\
\hline 1.37 & & 19000 & 3000 & 4000 & 230 \\
\hline 1.41 & & 18000 & & & 370 \\
\hline 0.97 & 2034 & 13000 & 3800 & 6400 & 680 \\
\hline 1.11 & & 8900 & 5800 & 3400 & 520 \\
\hline 1.41 & & 4600 & 1900 & 1500 & 39.) \\
\hline 1.78 & & 3800 & 1700 & 1400 & 330 \\
\hline 0.97 & 2847 & 11000 & 4300 & 6500 & 1800 \\
\hline 1.11 & & 13000 & 5300 & 3100 & 620 \\
\hline 1.41 & & 4900 & 2000 & 1600 & 440 \\
\hline 1.78 & & 5400 & 1600 & 1500 & 320 \\
\hline
\end{tabular}

The tracers were losded onto the column, and the flow rate was established at $0.015 \mathrm{~m} \ell /$ hour, which is equivalent to $9.5 \mathrm{~m} /$ year. Only technetium and europium were eluted from the column before the experiment was terminated after 241 days, although small amounts of barium were observed in the eluate occasionally. The technetium was removed in one peak, which contained $>96 \%$ of the ${ }^{95} \mathrm{Tc}^{\mathrm{m}}$ loaded. The $\mathrm{R}_{\mathrm{d}}$ for technetium corresponds to $0.84 \mathrm{~m} \ell / \mathrm{g}$, which fails within the range of measured batch sorption ratios for the Tunnel Bed tuff. 
Approximately $4 \%$ of the europium was removed from the column; the $R_{d}$ for europium calculated from this effluent observation is $2.3 \mathrm{~m} / \mathrm{g}$.

The crushed fracture-fill column was sectioned and counted to measure the distances that the remaining activities had traveled from the loading point. The remaining europium had moved 8 to $21 \%$ of the distance through the column. The europium sorption ratios are 988 to $2560 \mathrm{ml} / \mathrm{g}$, from this observation. Batch measurements gave $R_{d}$ values of 280 to $1000 \mathrm{~m} / \mathrm{g}$, a range that overlaps the values calculated for the europium that remained on the column. The europium that was eluted during the column experiment may have been in the form of a colloid. Such rapid elution of a fraction of the europium has been observed on other crushed-rock columns. 7 Very small amounts of the barium were observed in the eluate, but $84 \%$ of the ${ }^{133} \mathrm{Ba}$ was detected in the column section closest to the loading point. That section also contained $78 \%$ of the ${ }^{85} \mathrm{Sr}$ and $75 \%$ of the ${ }^{137} \mathrm{Cs}$. The remaining strontium, cesium, ani barium was detected in the section adjacent to the first section. The column was not sampled in small enough sections to measure the strontium, cesium, or barium concentrations. Hence, the $R_{d}$ values could not be calculated.

The crushed fracture-fill material from the Tunnel Bed tuff that was used in this column performed differently than any other material used in similar crushed rock column studies at Los Alamos. 7 Those other materials have included tuff from other sources, granite, and argillite. As the elution progressed in the column with the crushed fracture-fill material from the Tunnel Bed $t u f f$, the eluate became cloudy. The volume of the column material decreased with time, as the material in the column apparently broke apart. The elution process then removed fine particles.

\section{B. Solid Core Column}

A solid core of Tunnel Bed tuff was coated with epoxy to form a column. A detailed description of the core is given in Table XVII. A syringe pump was used to force tuff-treated Well J-13 water through the core for several weeks. The column was loaded with ${ }^{85} \mathrm{Sr},{ }^{137} \mathrm{Cs}$, and ${ }^{133} \mathrm{Ba}$. Well $\mathrm{J}-13$ water containing tritiated water (HTO), ${ }^{95} \mathrm{Tc}^{\mathrm{m}}$, and ${ }^{131} \mathrm{I}$ was used to elute the column until the radioactivity was equal to that of the initiai traced solution. At that time untraced water was used to continue the elution. The $R_{d}$ value calculated for ${ }^{95} \mathrm{Tc}^{\mathrm{m}}$. from this elution was $0.16 \mathrm{ml} / \mathrm{g}$. A1 though technetium sorption was not found on wafers, batch measurements on fracture-fill samples did give sorption ratios $\leq 1.8$. 
TABLE XVII

TUNNEL BED SOLID-CORE COLUMN

$\begin{array}{ll}\text { Diameter } & \\ \text { rock } & 1.67 \mathrm{~cm} \\ \text { rock + epoxy } & 1.75 \mathrm{~cm} \\ \text { Length } & 2.60 \mathrm{~cm} \\ \text { Density } & 1.25 \mathrm{~g} / \mathrm{cm}^{3} \\ \text { rock } & 1.16 \mathrm{~g} / \mathrm{cm}^{3} \\ \text { epoxy } & 1.24 \mathrm{~g} / \mathrm{cm}^{3} \\ \text { rock + epoxy } & 0.031 \mathrm{~m} \ell / \mathrm{hour} \\ \text { Flow rate } & 1.81 \mathrm{x} 10^{-5} \mathrm{~cm} / \mathrm{second} \\ & 5.7 \mathrm{~m} / \mathrm{year}\end{array}$

Free-column volume

HTO

$\mathrm{I}^{-}$

average

Porosity

Total volume eluted
$1.09 \mathrm{~m} \ell$

$1.39 \mathrm{~m} \ell$

$1.24 \mathrm{m \ell}$

0.218

$268 \mathrm{ml}$

After approximately 1 year the elution was stopped, and the distribution of activity remaining in the core was measured. The column was sampled by rubbing the damp core on tared pieces of silicon carbide paper. After they dried, the papers were reweighed to determine the amount of rock (and epoxy coating) removed in each sample. Sample sizes ranged from 12.8 to $40.9 \mathrm{mg}$, which is equivalent to the removal of $\cdots 43$ to $137 \mu \mathrm{m}$ per sample. Fifty-three samples were taken, which removed a total of $0.45 \mathrm{~cm}$. This detailed sampling gives a good indication of the extent of migration of the isotopes studied. The sample size, location in the column, and per cent of the total activity loaded in each sample are given in Table XVIII. When the average distance that each isotope moved through the column was plotted against each of the totals of strontium, cesium, and barium activity, the point within the column where $50 \%$ of the total activity had moved was determined. One-half of the strontium had 


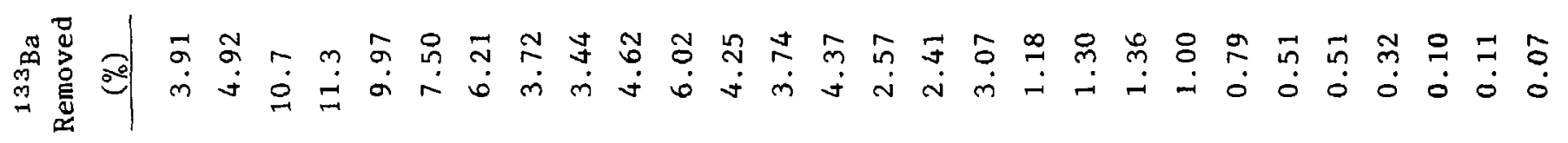

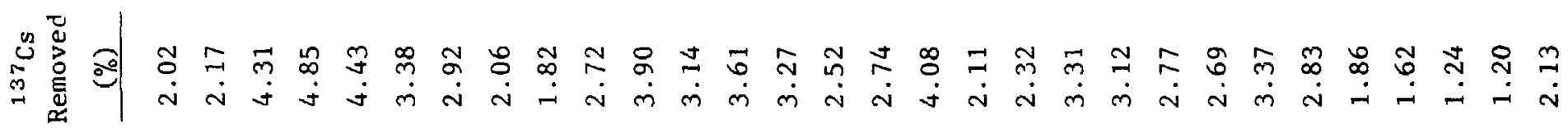

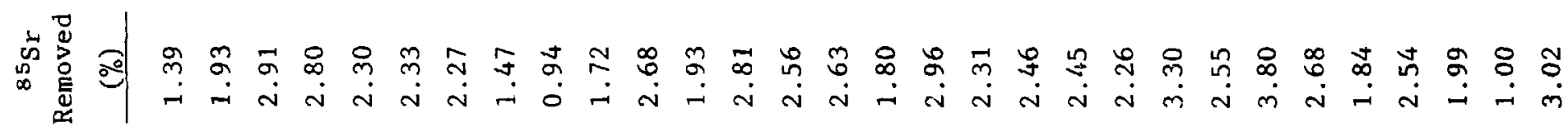

究

突总

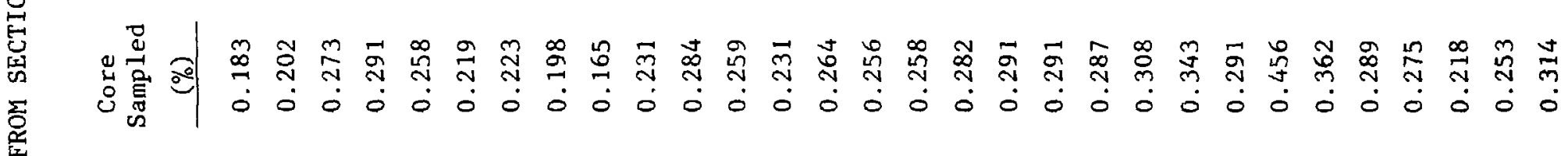

崖

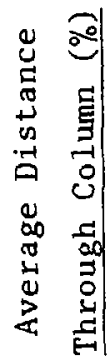

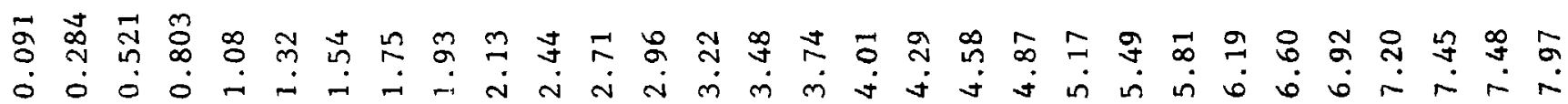


TABLE XVIII (cont)

\begin{tabular}{|c|c|c|c|c|}
\hline $\begin{array}{l}\text { Average Distance } \\
\text { Through Column }(\%)\end{array}$ & $\begin{array}{c}\text { Core } \\
\text { Sampled } \\
(\%) \\
\end{array}$ & $\begin{array}{c}{ }^{35} \mathrm{Sr} \\
\text { Removed } \\
(\%) \\
\end{array}$ & $\begin{array}{c}{ }^{137} \mathrm{Cs} \\
\text { Removed } \\
(\%) \\
\end{array}$ & $\begin{array}{c}133 \mathrm{Ba} \\
\text { Removed } \\
(\%) \\
\end{array}$ \\
\hline 8.30 & 0.347 & 1.74 & 1.30 & \\
\hline 8.63 & 0.317 & 1.44 & 1.49 & \\
\hline 8.93 & 0.296 & 2.15 & 1.07 & \\
\hline 9.24 & 0.333 & 1.82 & 1.32 & \\
\hline 9.56 & 0.352 & 2.36 & 1.37 & \\
\hline 9.98 & 0.446 & 2.18 & 1.28 & \\
\hline 10.5 & 0.518 & 2.18 & 1.03 & \\
\hline 10.9 & 0.427 & 1.94 & 1.05 & \\
\hline 11.4 & 0.527 & 2.03 & 0.73 & \\
\hline 11.9 & 0.369 & 2.11 & 0.54 & \\
\hline 12.2 & 0.393 & 2.02 & 0.53 & \\
\hline 12.6 & 0.405 & 1.55 & 0.34 & \\
\hline 13.1 & 0.436 & & 0.37 & \\
\hline 13.5 & 0.468 & 2.25 & 0.28 & \\
\hline 13.9 & 0.400 & 1.65 & 0.25 & \\
\hline 14.3 & 0.345 & & 0.18 & \\
\hline 14.7 & 0.366 & & 0.19 & \\
\hline 15.0 & 0.380 & & 0.16 & \\
\hline 15.4 & 0.410 & & 0.12 & \\
\hline 15.8 & 0.367 & & 0.09 & \\
\hline 16.2 & 0.421 & & & \\
\hline 16.7 & 0.432 & & & \\
\hline 17.1 & 0.481 & & & \\
\hline Remaining core & & 2.79 & 0.59 & \\
\hline
\end{tabular}


moved $5.5 \%$ of the way through the column, indicating $4873 \mathrm{~m} \ell$ would be required to remove $50 \%$ of the ${ }^{85} \mathrm{Sr}$. One-half of the cesium and barium had moved 3.74 to $3.86 \%$ and 1.35 to $1.56 \%$, respectively. Therefore, 17200 to $19800 \mathrm{~m} \ell$ would be needed to remove $50 \%$ of the ${ }^{133} \mathrm{Ba}$, and 6900 to $7200 \mathrm{ml}$ would be needed to remove $50 \%$ of the ${ }^{137} \mathrm{Cs}$. The sorption ratios calculated from the solid-core data are $690 \mathrm{~m} \ell / \mathrm{g}$ for ${ }^{85} \mathrm{Sr}, \sim 1000 \mathrm{~m} \ell / \mathrm{g}$ for ${ }^{137} \mathrm{Cs}$, and $2600 \mathrm{~m} \ell / \mathrm{g}$ for ${ }^{133} \mathrm{Ba}$. The ranges of sorption ratios for strontium, cesium, and barium sorbed ontc the same tuff in the form of wafers are quite large: 430 to $19000 \mathrm{ml} / \mathrm{g}$ for ${ }^{85} \mathrm{Sr}$, 1600 to $10000 \mathrm{ml} / \mathrm{g}$ for ${ }^{137} \mathrm{Cs}$, and 360 to $25000 \mathrm{ml} / \mathrm{g}$ for ${ }^{133} \mathrm{Ba}$. The $R_{\mathrm{d}}$ values for ${ }^{85} \mathrm{Sr}$ and ${ }^{133} \mathrm{Ba}$, calculated from the solid core elution, fall within the range of measured wafer values. The $R_{d}$ value for ${ }^{137}$ Cs appears to be somewhat higher when measured by the wafer sorption technique. The very large ranges of sorption ratios on the Tunnel Bed tuff, measured by a variety of techniques on both crushed and intact material, make comparisons difficult. Such a large variability in experimental results from a single sample of tuff has not been found for other tuffs, such as those from Yucca Mountain and Wel1 J-13 in Jackass Flats. The reasons for the large variations in the sorption studies on the Tunnel Bed tuffs from G-Tunnel are unknown.

\section{ACTINIDE SORPTION MEASUREMENTS}

\section{A. Uranium Sorption}

Uranium sorption onto crushed Tunnel Bed tuff was measured as a function of the $\mathrm{pH}$ of the initial solution. The initial pH values were adjusted with hydrochloric acid or sodium hydroxide solutions. The tuff was from core U12GRNM9, and the material was crushed to a particle size <355 $\mu \mathrm{m}$. Both sorption and desorption $R_{d}$ values were measured, and the contact times for each were 6 days. The tracer was uranyl nitrate with normal isotopic composition. After conclusion of the experiments, the uranium concentrations were assayed by neutron activation followed by delayed-neutron counting.

The results of this experiment are given in Table XIX. The variation in sorption ratios with $\mathrm{pH}$ may be the result of differences in the species of uranium present. For example, D. Langmuir ${ }^{8}$ reports the stability of a variety of uranium species at $10^{-2}$ atm $\mathrm{CO}_{2}$, ranging from $\mathrm{UO}_{2}^{2+}$ in acid solution through a series of neutral and anionic complexes to $\mathrm{NO}_{2}\left(\mathrm{CO}_{3}\right)_{4}^{4-}$ in the $\mathrm{pH}$ range investigated in this study. 
TABLE XIX

U(VI) PH-ADJUSTED SORPTION RATIOS ON U12G-RNM9 CRUSHED TUFF

\begin{tabular}{|c|c|}
\hline Original & Final \\
\hline 4.0 & 7.1 \\
\hline 4.0 & 6.3 \\
\hline 6.0 & 7.8 \\
\hline 6.0 & 7.3 \\
\hline 7.0 & 8.6 \\
\hline 7.0 & 8.6 \\
\hline 8.0 & 8.7 \\
\hline 8.0 & 8.6 \\
\hline 10.0 & 9.1 \\
\hline 10.0 & 8.8 \\
\hline
\end{tabular}

$\frac{\mathrm{R}_{\mathrm{d}}(\mathrm{m} \ell / \mathrm{g})}{\text { Sorption }}$

405

2400

137

$1 \quad 050$

36

83

18

51

9

43

B. Neptunium, Plutonium, and Americium Sorption

A series of sorption ratins measurements was undertaken to compare the results obtained when different experimental techniques were used with identical tuff samples and actinide tracer solutions. The tracers were contacted with the crushed tuff in two ways: (1) by using the conventional batch technique, in which the tuff and the tracer solution are shaken together in a closed bottle and (2) by using a pump to recirculate the tracer solution through a column of tuff, which is essentially a batch contact system without physical movement of the tuff. The two were compared to see if the physical concact of the tuff particles with each other during shaking in a batch experiment might produce finer particles that would give different sorption ratios than those obtained from a circulating system in which the tuff did not move.

The Tunnel Bed tuff used for these measurements came from core U12G-RNM9, 8.1 to $10.0 \mathrm{ft}$, crushed to 106 to $250 \mu \mathrm{m}$. The contact times were $3,6,9$, and 12 weeks for sorption and $12,9,6$, and 3 weeks for desorption, unless otherwise noted in the data tables. The tracer concentrations that were used were $1.6 \times 10^{-11} \mathrm{M}$ for neptunium, $4.8 \times 10^{-12} \mathrm{M}$ for plutonium, and $9.2 \times 10^{-8} \mathrm{M}$ for americium. 
The sorption ratios for the circulating and batch comparisons are shown in Table XX. Contrary to expectations, the $R_{d}$ value for sorption is higher both for plutonium and for americium in the circulating system than in the batch system. The reason for this observation is not known.

Another comparison was made between $R_{d}$ values for neptunium measured in a batch system in air and those measured in a similar batch system in a controlled atmosphere. The data for this comparison are shown in Table XXI. The exclusion of oxygen and carbon dioxide resulted in higher $\mathrm{R}_{\mathrm{d}}$ values both for sorption and for desorption than when they were measured in air.

TABLE XX

COMPARISON OF SORPTION RATIOS FROM CIRCULATING SYSTEM AND BATCH EXPERIMENTS

$\mathrm{R}_{\mathrm{d}}(\mathrm{m} 2 / \mathrm{g})$

\begin{tabular}{|c|c|c|c|c|}
\hline \multirow[b]{2}{*}{ Tracer } & \multicolumn{2}{|c|}{ Circulating System ${ }^{a}$} & \multicolumn{2}{|c|}{ Batch ${ }^{a}$} \\
\hline & Sorption & Desorption & Sorption & Desorption \\
\hline Neptunium & $34(2)$ & 51 (3) & $36(2)$ & $60(3)$ \\
\hline Plutonium ${ }^{c}$ & $820(140)$ & & $300(90)$ & \\
\hline Americium ${ }^{d}$ & $3100(700)$ & & $800(50)$ & \\
\hline
\end{tabular}

${ }^{a}$ Values of duplicate analyses are given, with the standard deviations of the means in parentheses.

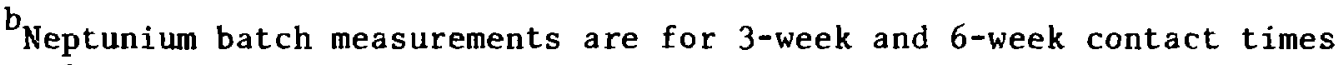
only.

${ }^{C}$ Plutonium measurements did not include 9-week contact times, and the initial contact time for the circulating system was 4 weeks.

d Americium measurements for circulating system include 3-week and 6-week contact times only. 
TABLE XXI

COMPARISON OF NEPTUNIUM BATCH SORPTION MEASUREMENTS

MADE IN AIR AND IN A CONTROLLED ATMOSPHERE ${ }^{\mathrm{a}}$

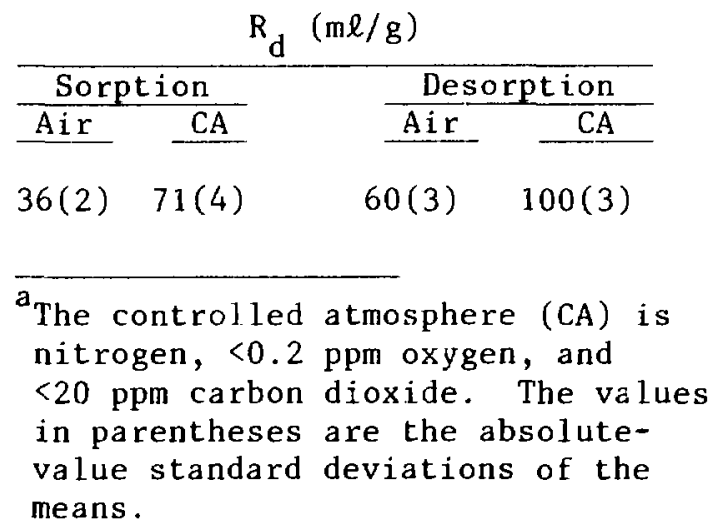

VII. CALCULATIONS OF RADIONUCLIDE MIGRATION IN FRACTURED TUFF

These geochemical studies were part of a program to determine the extent of radionuclide migration during groundwater flow through a fracture in Tunnel Bed tuff. Therefore, theoretical studies of the consequences of groundwater flow through a fracture are of interest for this work. The results from two types of calculations are given in this section. The first type is based on a one-dimensional model of fracture flow plus matrix diffusion, and the second type of calculation includes velocity dispersion and porous flow in a threedimensional tuff matrix.

\section{A. One-Dimensional Fracture Flow with Matrix Diffusion}

The importance of matrix diffusion during groundwater flow through a fracture in tuff was investigated in the following model study. The analytical solution for radionuclide transport of this type has been given by I. Neretnieks. ${ }^{9}$

Diffusion in the tuff matrix can be described by the following equation:

$$
\frac{\partial C_{p}}{\partial t}=D_{\text {app }} \frac{\partial^{2} C_{p}}{\partial z^{2}}-\lambda C_{p}
$$


in which

$$
\begin{aligned}
C_{p} & =\text { concentration of the radionuclide in the water in pores, } \\
t & =\text { time, } \\
D_{a p p} & =\frac{D_{e f f}}{K_{d} \rho}, \\
D_{e f f} & =\varepsilon_{p} \frac{\alpha}{\tau} D^{i}, \\
\varepsilon_{p} & =\text { matrix porosity, } \\
\alpha & =\text { constrictivity of the pores, } \\
\tau & =\text { tortuosity of the pores, } \\
D^{i} & =\text { ionic diffusion coefficient, } \\
K_{d} \rho & =\text { volumetric sorption ratio, equal to } \varepsilon_{p}+\left(1-\varepsilon_{p}\right) K_{d}^{\prime} \rho_{s}, \\
K_{d}^{\prime} & =\text { distribution coefficient, } \\
\rho_{s} & =\text { density of the solid, } \\
z & =\text { distance into the matrix from the fracture surface, and } \\
\lambda & =\text { radioactive decay constant. }
\end{aligned}
$$

Sorption and convection are given by

$$
\frac{\partial C_{f}}{\partial t}+U_{f} \frac{\partial C_{f}}{\partial x}=\left.\frac{D_{\text {eff }}}{b} \frac{\partial C_{p}}{\partial z}\right|_{z=0}-\lambda C_{f}
$$

in which the symbols not defined previously are

$$
\begin{aligned}
& \mathrm{C}_{\mathrm{f}}=\text { concentration of the radionuclide in the water in fissures, } \\
& \mathrm{U}_{\mathbf{f}}=\text { water velocity, } \\
& \mathbf{x}=\text { distance along the fracture, and } \\
& \mathbf{b}=\text { half-width of the fracture. }
\end{aligned}
$$


The solution to these equations with the appropriate boundary and initial conditions for a concentration step of duration $\Delta t$ is

$$
\begin{array}{r}
\frac{C_{p}}{C_{0}}=e^{-\lambda t}\left(\operatorname{erfc}\left\{\frac{G}{\left[t_{w}-\left(t_{0}+t\right)\right]^{1 / 2}}\right\}\right. \\
\left.\quad-\operatorname{erfc}\left\{\frac{G}{\left[t-\left(t_{w}+t_{0}+\Delta t\right)\right]^{1 / 2}}\right\}\right),
\end{array}
$$

in which

$$
\begin{aligned}
& G=\left\{\left[D_{\text {eff }}+\frac{1}{2} \frac{U_{f}(2 b) z}{x}\right] / 2 b\left(D_{\text {app }}\right)^{1 / 2}\right\} t_{w}, \\
& t_{w}=\text { the time required for the water to reach } x \text {, and } \\
& t_{0}=\text { the initial time. }
\end{aligned}
$$

The nominal parameter values chosen for use in these calculations are shown in Table XXII. These values were derived from the measured properties of Tunnel Bed tuff. The ionic diffusion coefficient value corresponds to that of strontium. This value is intermediate between the ionic diffusivities of most monovalent and divalent ions. Fissure apertures from 10 to $100 \mu \mathrm{m}$ and flow velocities $\left(U_{f}\right)$ from 1 to $100 \mathrm{~m} /$ day were used in the calculations.

Figure 1 shows the activity profile for a nonsorbing tracer, $K_{d}^{\prime}=0$, with a flow rate of $1 \mathrm{~m} /$ day after 300 days. Although the water has traveled $300 \mathrm{~m}$, the activity has traveled only $9 \mathrm{~cm}$. This result is caused by the loss of tracer to the rock matrix. In Fig. 2, tracer is shown to have penetrated far beyond $1 \mathrm{~cm}$. This apparent retardation occurs because the concentration gradient is highest and the diffusion fastest at the tracer front; therefore, the activity in the leading edge is lost to the marrix until the concentration in the matrix builds up. Figures 3 to 6 show similar profiies at fluid velocities of 10 and $100 \mathrm{~m} /$ day. At $100 \mathrm{~m} /$ day the tracer begins to exis the $1-\mathrm{m}$ fracture in 0.3 days, and at $10 \mathrm{~m} /$ day the traser front $\left(C / c_{0}=0.5\right)$ moves $10 \mathrm{~cm}$ in 3 days.

Figures 7,8 , and 9 show the surface profile for sorbing tracers with a fluid velocity of $100 \mathrm{~m} /$ day. Tracers having $K_{d}$ values $\leq 1000 \mathrm{~m} \ell / \mathrm{g}$ will move more 
TABLE XXII

PHYSICAL PARAMETERS USED FOR MATRIX DIFFUSION

CALCULATIONS WITH TUNNEL BED TUFF

Parameter

Density

Matrix porosity

Constrictivity/tortuosity

Ionic diffusion coefficient

Effective diffusion coefficient
Symbol

$\rho$

$\varepsilon \mathbf{p}$

$\alpha / \tau^{2}$

$\mathrm{D}^{\mathrm{i}}$

$D_{\text {eff }}$ $\frac{\text { Value }}{1.6 \mathrm{~g} / \mathrm{cm}^{3}}$

0.30

0.10

$7.74 \times 10^{-10} \mathrm{~m}^{2} / \mathrm{s}$

$2.71 \times 10^{-11} \mathrm{~m}^{2} / \mathrm{s}$

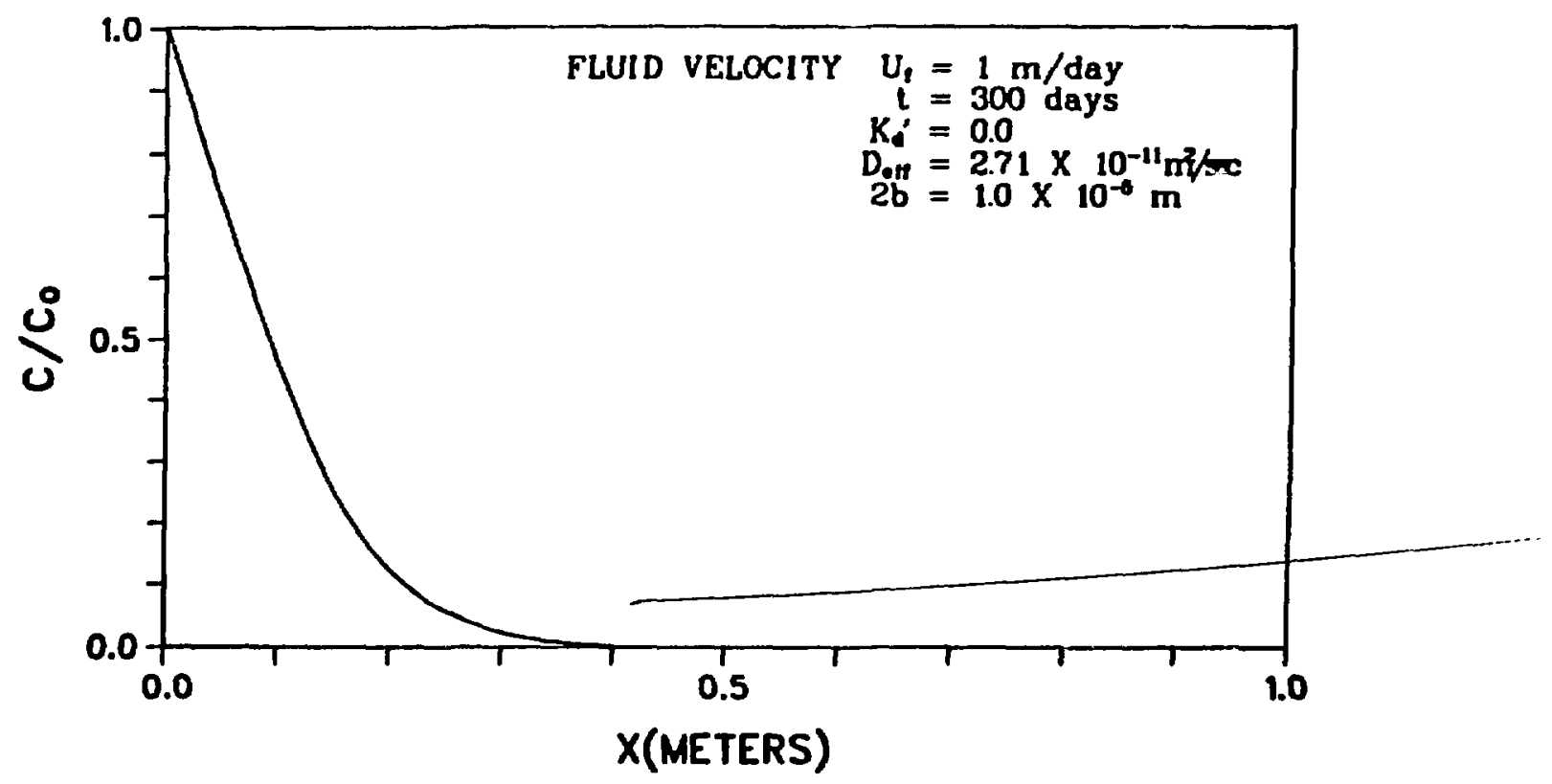

Fig. 1. Concentration profile on the fracture surface $(z=0)$. 


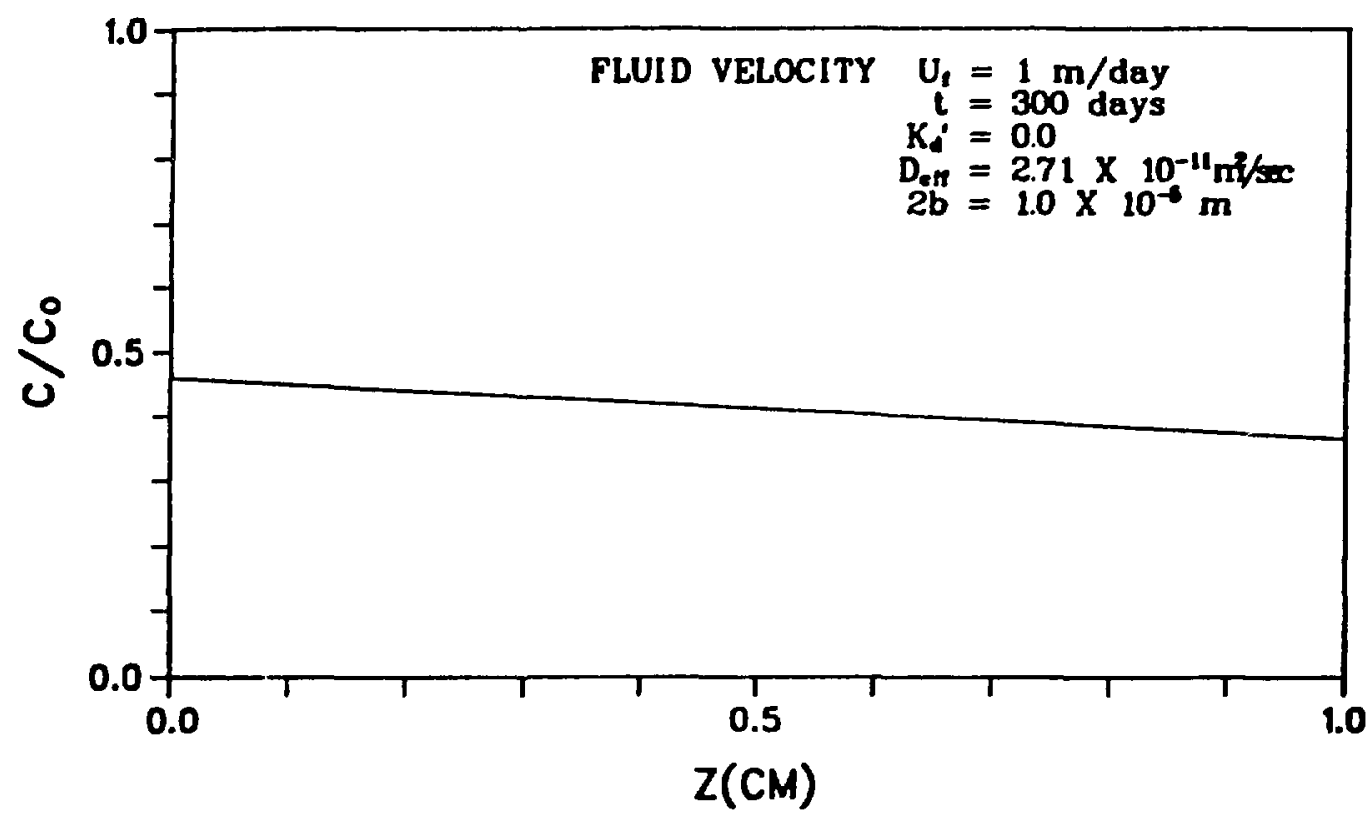

Fig. 2. Concentration profile in the rock matrix $(x=0.1 \mathrm{~m})$.

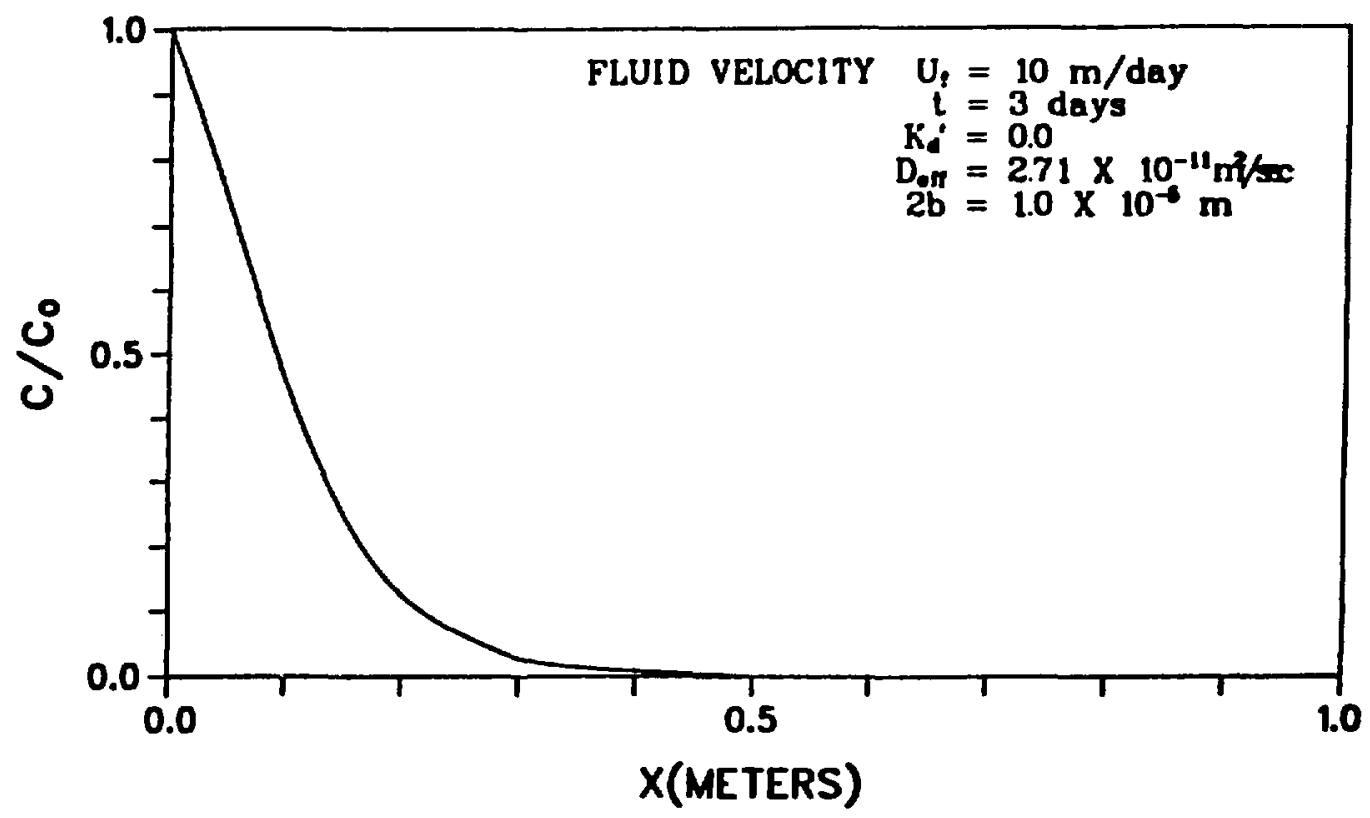

Fig. 3. Concentration profile on the fracture surface $(z=0)$. 


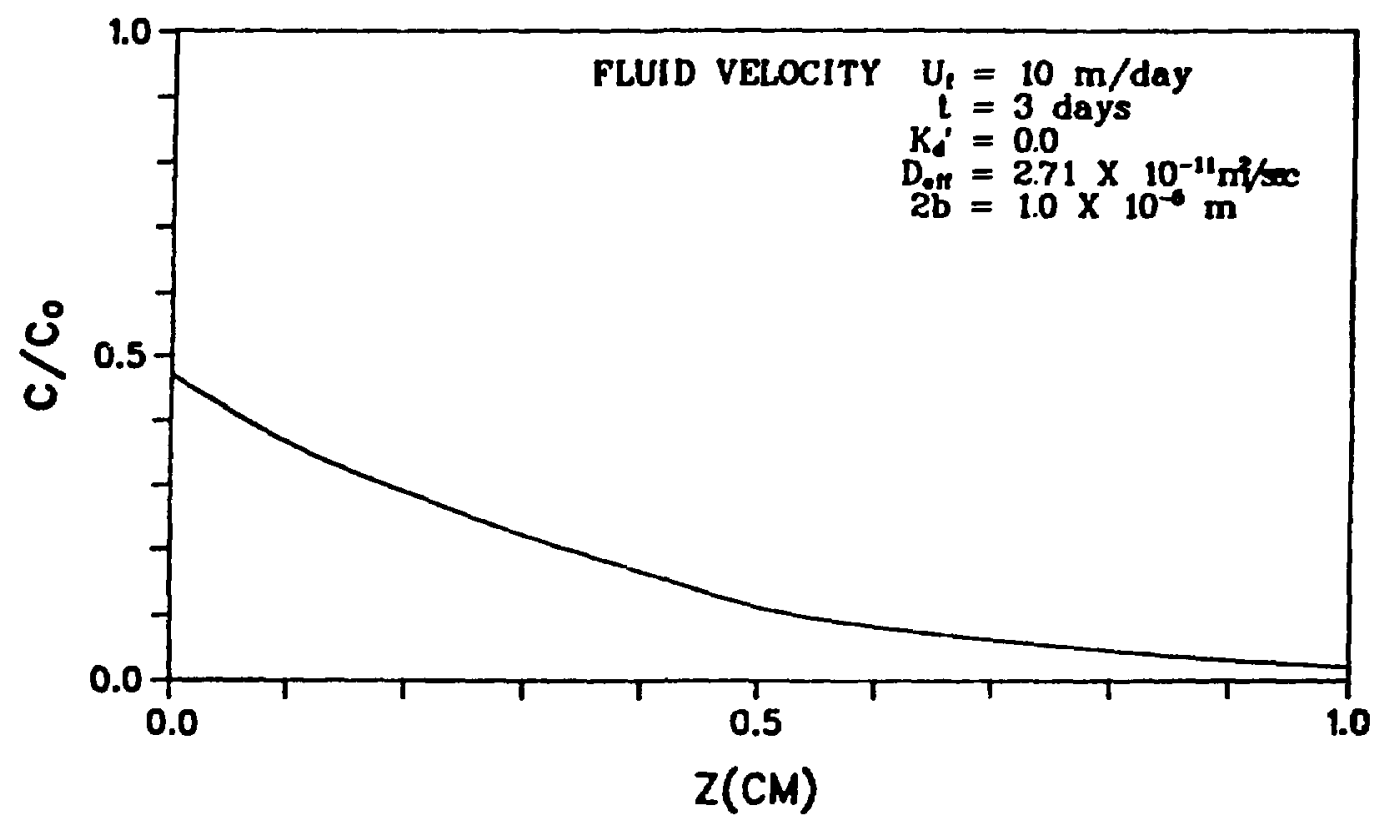

Fig. 4. Concentration profile in the rock matrix $(x=0.1 \mathrm{~m})$.

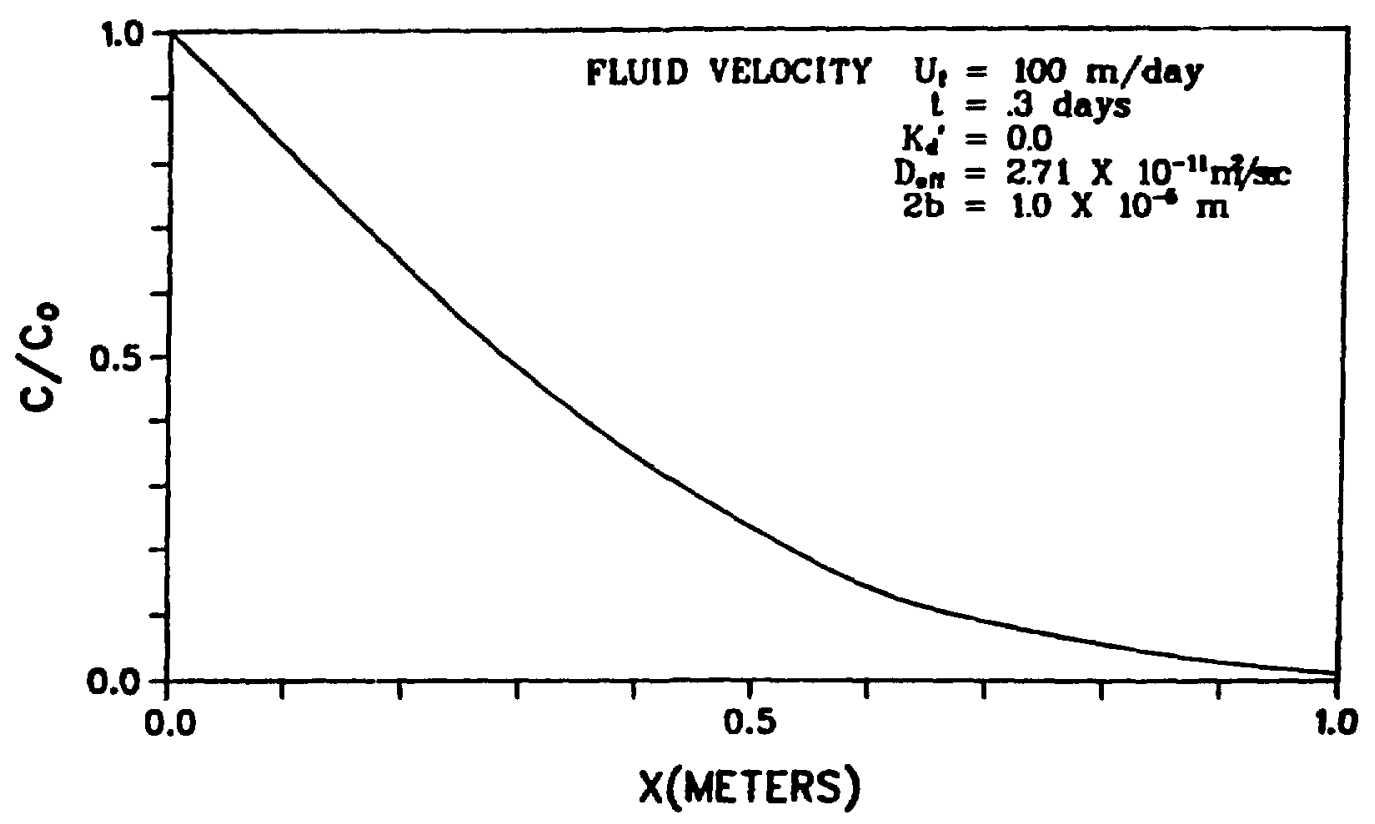

Fig. 5. Concentration profile on the fracture surface $(z=0)$. 


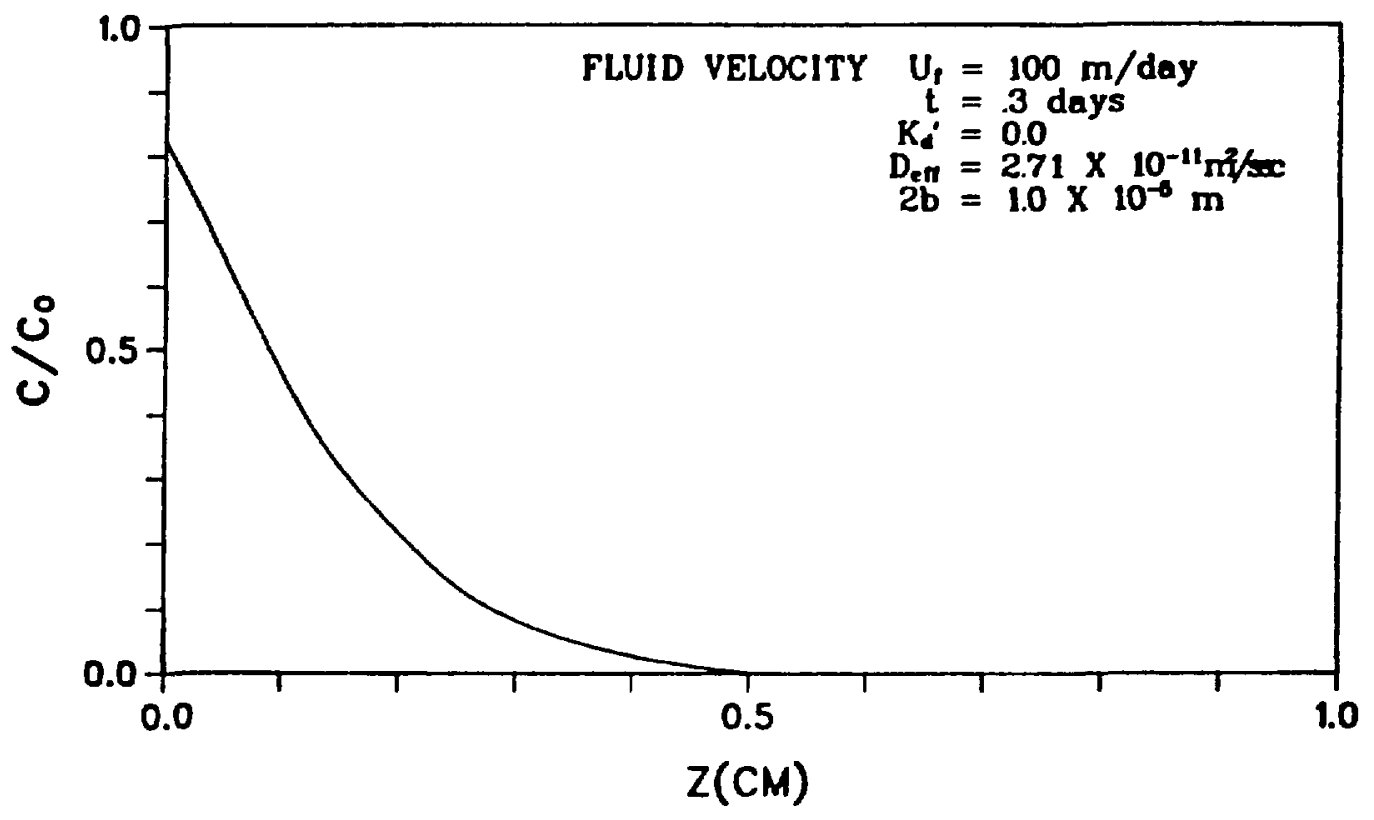

Fig. 6. Concentration profile in the rock matrix $(x=0.1 \mathrm{~m})$.

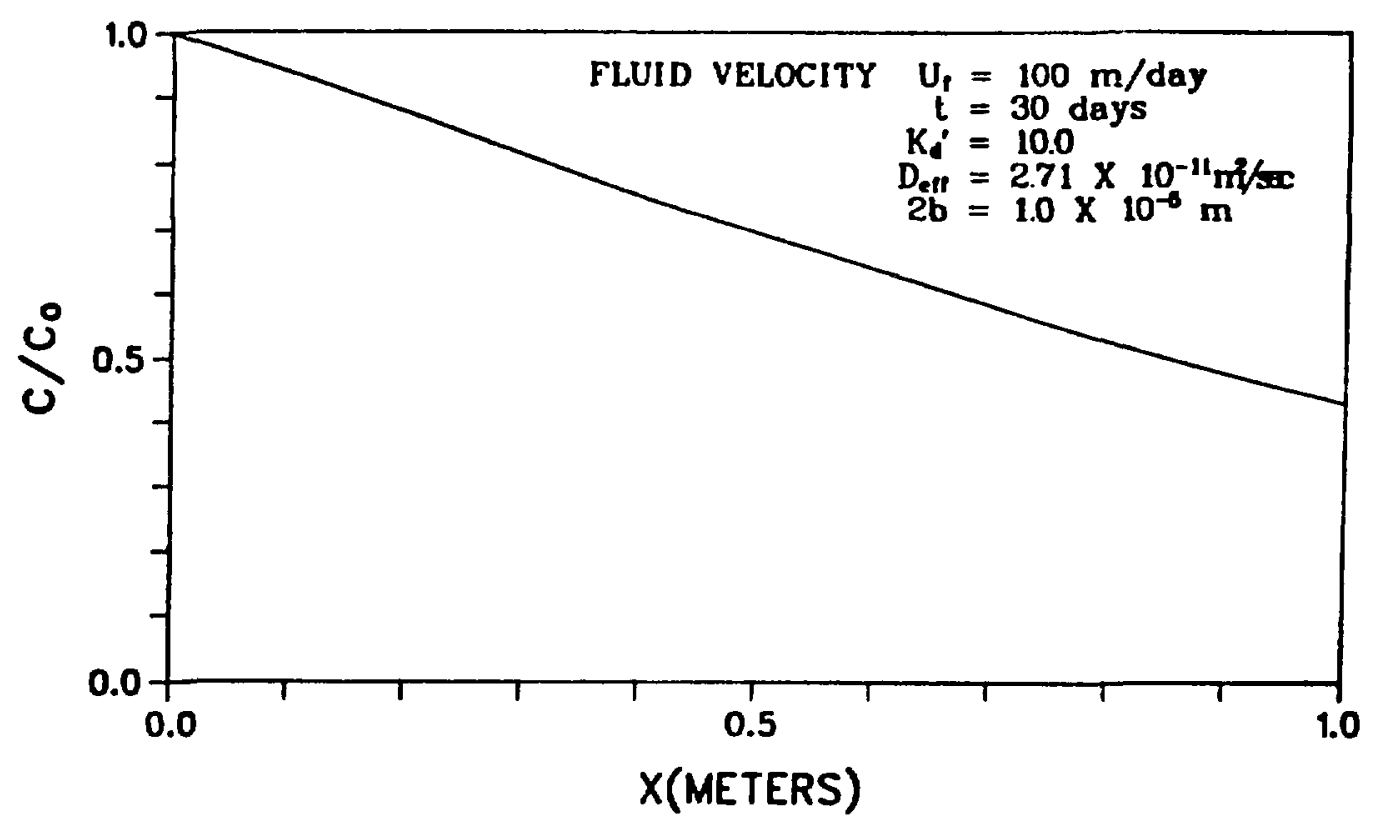

Fig. 7. Concentration profile on the fracture surface $(z=0)$. 


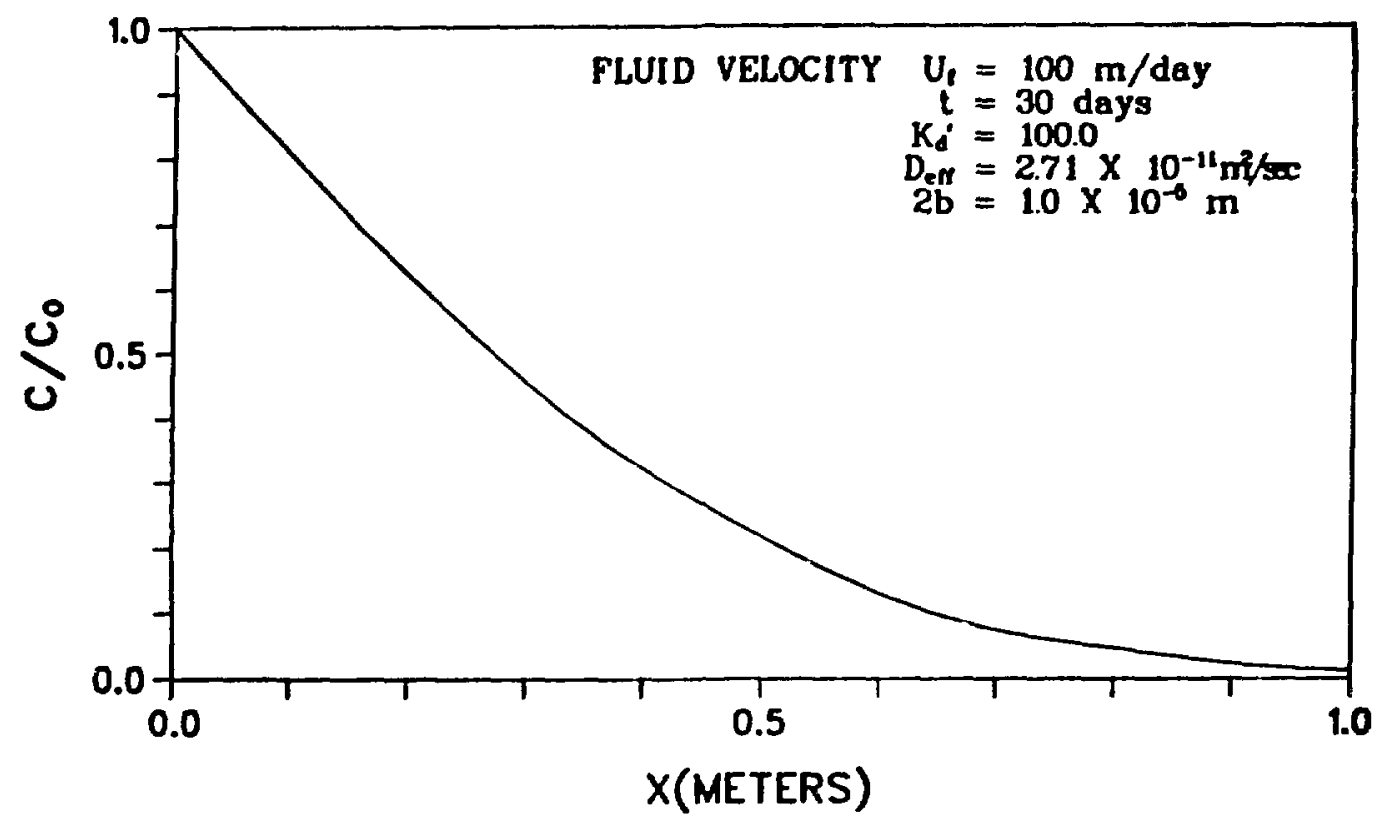

Fig. 8. Concentration profile on the fracture surface $(z=0)$.

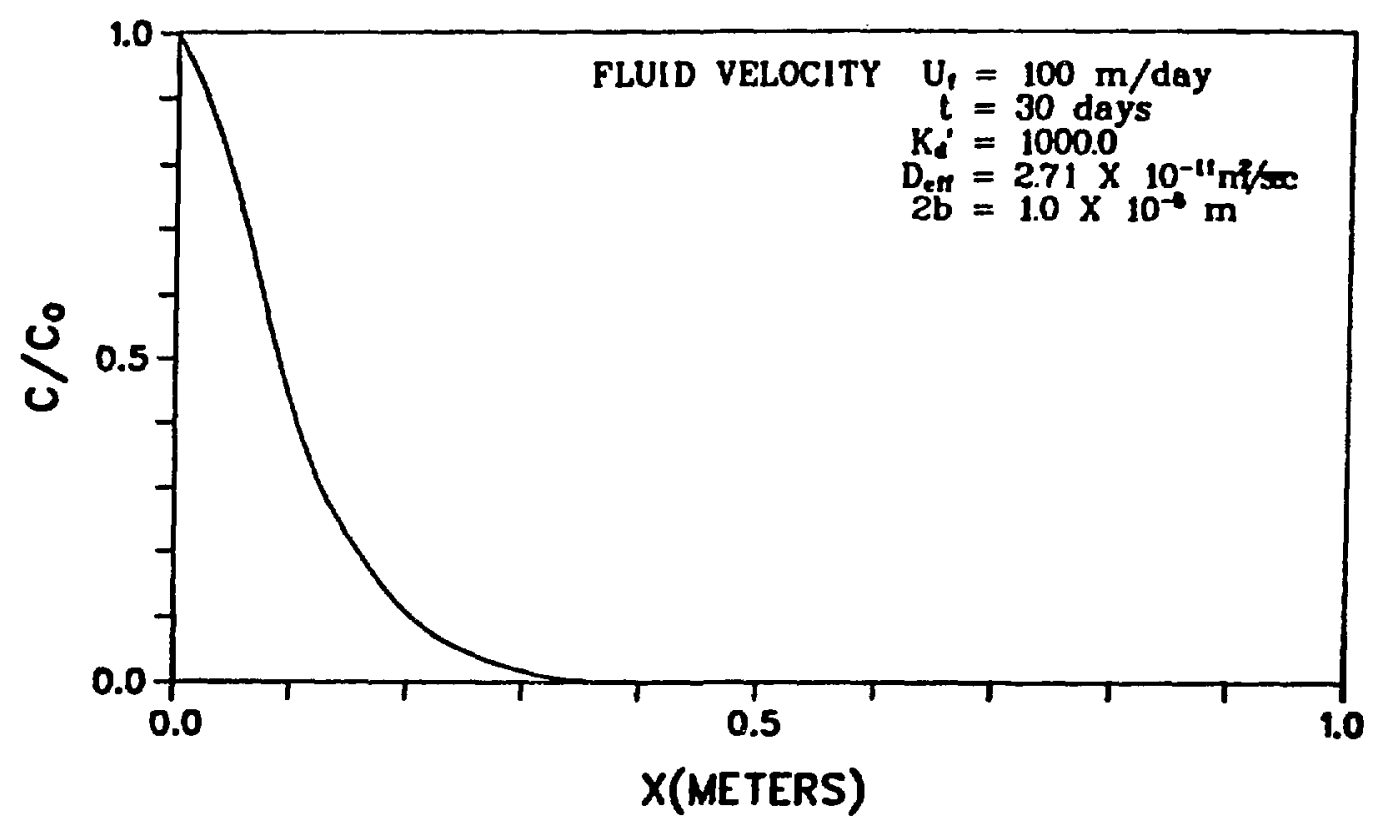

Fig. 9. Concentration profile on the fracture surface $(z=0)$. 
than $10 \mathrm{~cm}$ in 30 days. Figure 10 shows the effect of having a 100- $\mu \mathrm{m}$ fissure aperture. A larger aperture would make it possible to use tracers with much higher $K_{d}$ values or to use slower fluid velocities. However, the latter may be the only option available if equipment design limits the flow rates that can be introduced into the fracture.

Some interesting relationships are evident in these calculations. (1) To a first approximation, the distance that a given tracer travels in some fixed time interval depends on the flow rate, independent of the aperture. (2) The distance that a given tracer travels in a fixed time interval varies as the square root of the $K_{d}$ value for a fixed fluid velocity.

\section{B. TRACR3D}

A computer code named TRACR3D is being used to model transient air, water, and tracer flow in tuff in a three-dimensional geometry. This code incorporates such transport mechanisms as advection, molecular diffusion, and capillary action. Some of the results from the first calculation with this code are shown

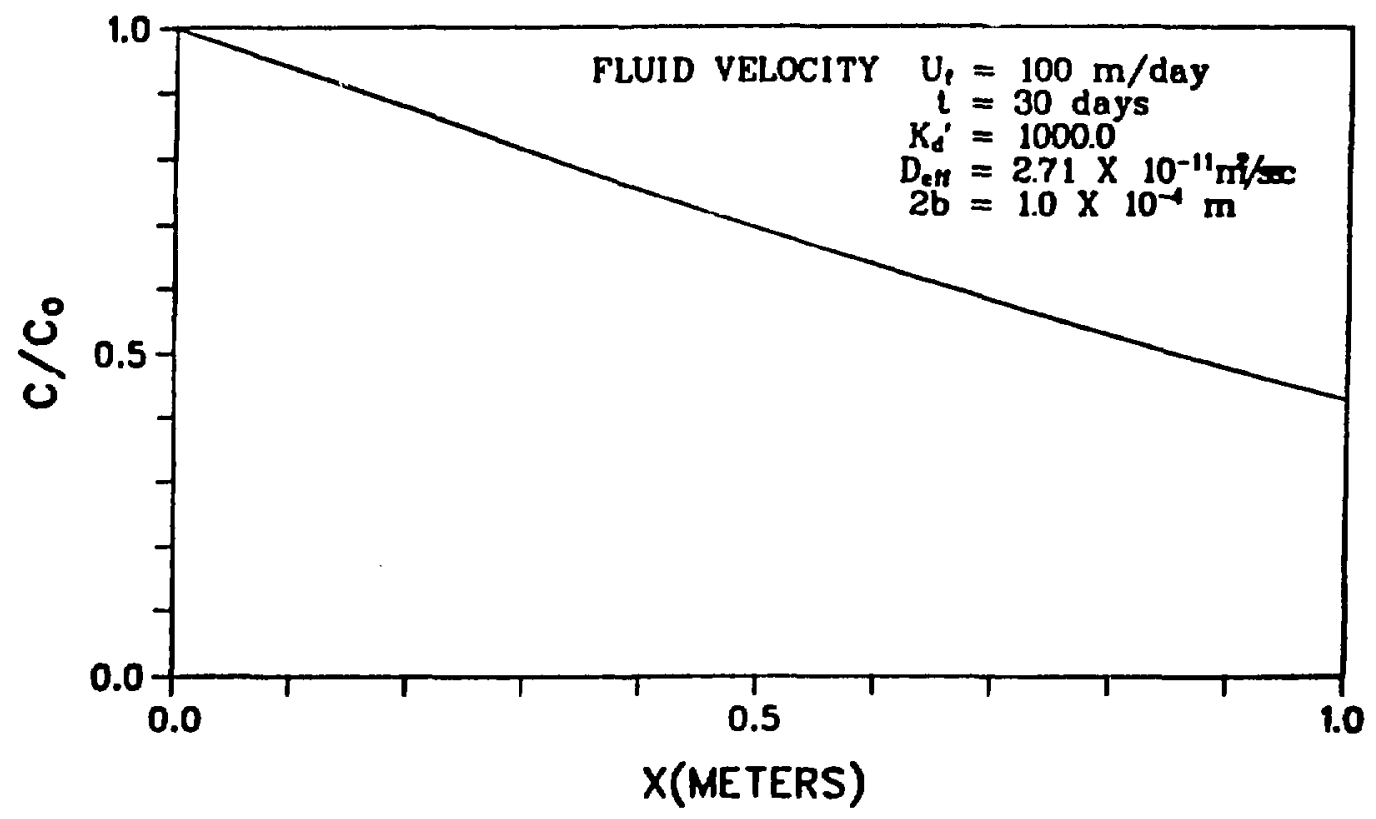

Fig. 10. Concentration profile on the fracture surface $(z=0)$. 
in Figs. 11-13. The problem is that of calculating tracer flow in a fracture when the tracer is injected into the fracture from a single borehole and is collected at eight sampling holes regularly spaced in a circular pattern $2 \mathrm{~m}$ from the injection point. The geometry of the problem is shown in Fig. 11, with the parameter values that were used. Symmetry reduces the calculation to that of flow in the $22.5^{\circ}$ wedge that is shown.

The pressure distribution that would evolve in the horizontal fracture and in the tuff above it following 90 days of water injection is shown in Fig. 12. The plot shows pressure contours on a vertical-plane slice through the axis of the borehole at an angle of $0^{\circ}$ from the front face shown in Fig. 11. The pressure drops rapidly because of the strong radial divergence. Figure 13 displays water saturation after 90 days in the same plane as Fig. 12. Water inflow remained virtually constant at $1.1 \mathrm{l} /$ day. The plot shows that the matrix is saturated only to a radius of $1 \mathrm{~m}$ and a height of several centimeters. Capillary action has smeared the saturation front.

Additional calculations will be performed to help guide the experimental fracture-flow nuclide migration program.

\section{CONCLUSIONS}

This laboratory study of Tunnel Bed 5 cuff was undertaken to measure geochemical properties pertinent for a radionuclide migration field experiment. The tuff occurs as a bedded ash fall. The $x$-ray diffraction studies showed that the tuff consists of 60 to $90 \%$ zeolitized material. The porosity was measured in the range 0.31 to 0.40 . The median pore diameter is approximately $0.6 \mu \mathrm{m}$. The permeability of this tuff ranges from $1 \times 10^{-18}$ to $9 \times 10^{-19} \mathrm{~m}^{2}$.

The sorption characteristics of radioactive tracers were measured in experiments with crushed tuff, with tuff in the form of wafers, and with solid cores of tuff. The water used in these sorption determinations was NTS Well J-13 water that had been contacted with Tunnel Bed 5 tuff for a week, then filtered through $0.05-\mu m$ Nuclepore polycarbonate filters. Use of a filter with this small pore size was necessary to eliminate the fine particles that Tunnel Bed 5 tuft produced when contacted with water. The sorption ratio data from all the experiments can be generalized by grouping the tracers used into three categories: (1) tracers with high sorption ratios: ${ }^{85} \mathrm{Sr},{ }^{137} \mathrm{Cs}$, and ${ }^{133} \mathrm{Ba}$; (2) tracers with intermediate sorption ratios: ${ }^{54} \mathrm{Mn},{ }^{113} \mathrm{Sn},{ }^{152} \mathrm{Eu}$, and ${ }^{237} \mathrm{Pu}$; and (3) tracers with low sorption ratios: ${ }^{75} \mathrm{Se},{ }^{95} \mathrm{Tc}{ }^{\mathrm{m}},{ }^{131} \mathrm{I},{ }^{238} \mathrm{U}$, and ${ }^{235} \mathrm{~Np}$. These results are about what one would expect for a zeolitized tuff. 


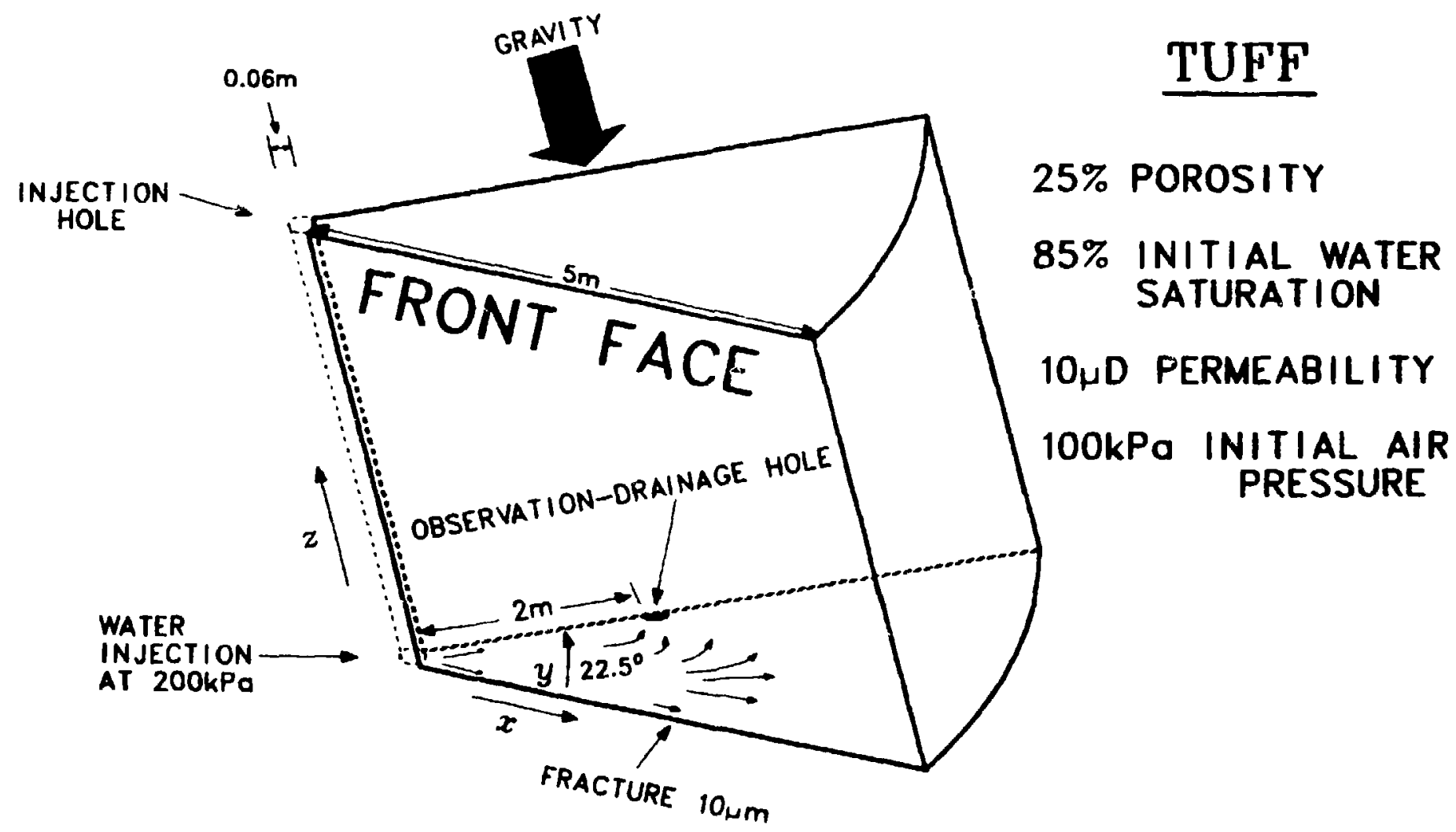

Fig. 11. Cylindrical geometry used in three-dimensional flow calculations. 


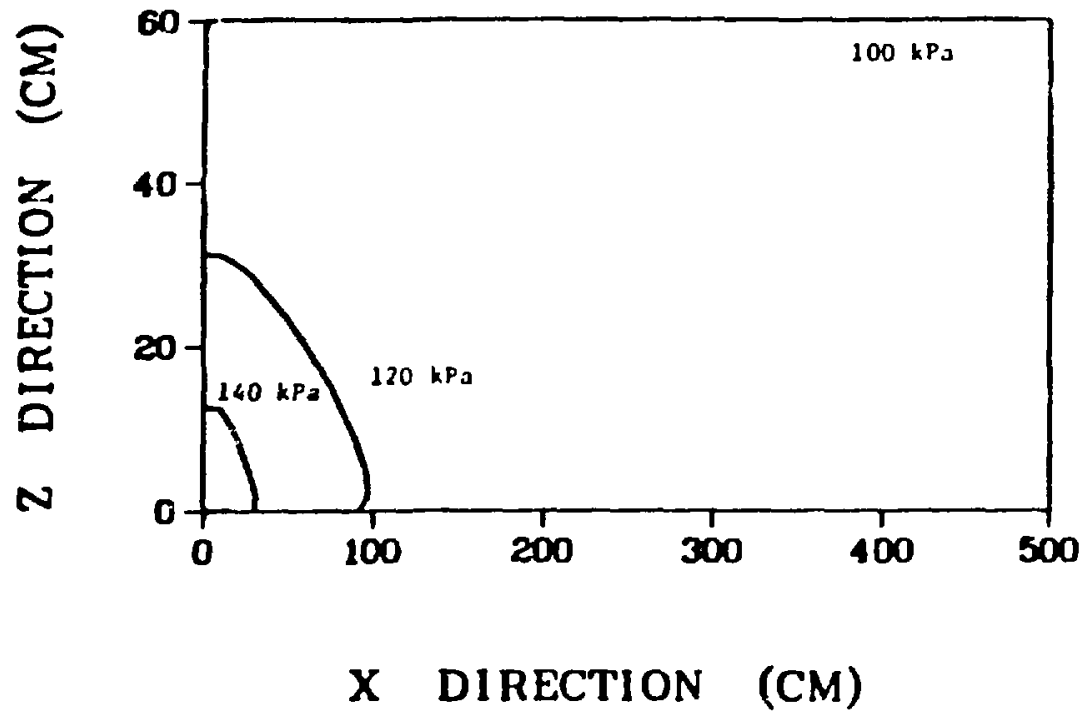

Fig. 12. Pressure contcurs 90 days after start of water injection.

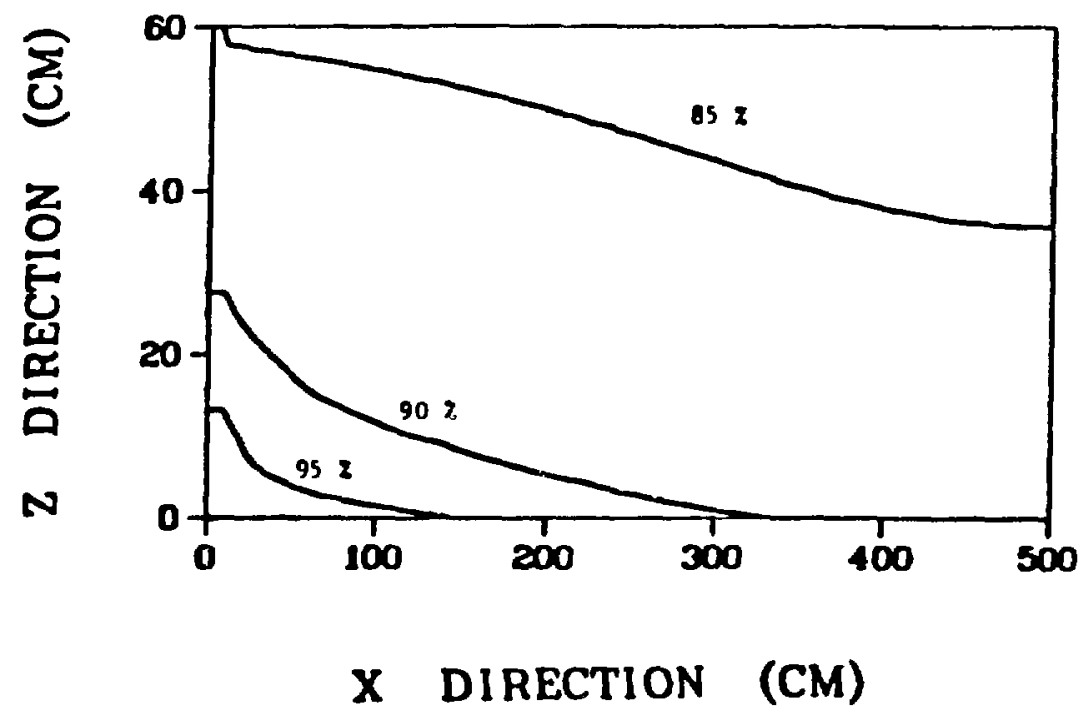

Fig. 13. Water saturation contours 90 days after start of water injection. 
What was unexpected in the results of these laboratory measurements was the poor reproducibility of the data in comparison to sorption ratio measurements with other tuffs. The poor reproducibility may be related to the tendency of the Miocene tunnel bed tuff to form fine particles when contacted with water. The order of magnitude differences in sorption ratios for some of the results in similar experiments are otherwise inexplicable.

These laboratory studies indicate that Tunnel Bed 5 tuff would be of questionable suitability for a fracture-flow nuclide migration field experiment. The primary purpose for the field experiment is to validate computer models of radionuclide sorption under fracture-flow conditions. Field tests that would be as irreproducible as these laboratory studies would be of limited use in providing experimental verification of model predictions.

Theoretical studies of the consequences of groundwater flow through a fracture were undertaken with two computer codes. A one-dimensional calculation of fracture flow plus matrix diffusion indicated that, to a first approximation, the distance that a given tracer travels in a fixed time interval depends on the flow rate, but not the size of the fracture aperture. Furthermore, the distance that a tracer travels in a fixed time interval varies as the square root of the $K_{d}$ value for a fixed fluid velocity. The first results, from a three-dimensional calculation for a material saturated only to $85 \%$ with groundwater, showed the difficulty of performing a fracture-flow experiment because of capillary action, which resulted in adsorption of the water in the fracture.

\section{ACKNOWLEDGMENTS}

The radioactive samples were counted by P. A. Elder, M. E. Lark, and S. Lermuseaux. The final drafts of this manuscript were typed by $L$. M. Mitchell.

\section{REFERENCES}

1. B. R. Erdal, K. Wolfsberg, J. K. Johnstone, K. L. Erickson, A. M. Friedman, S. Fried, and J. J. Hines, "Nuclide Migration Field Experiments," Los Alamos Pationa1 Laboratory report LA-8487-MS (March 1981).

2. 1979 Annu: 1 Book of ASTM Standards: Part XIX Soils and Rocks; Building Stones Stanciard Test Method for Specific Gravity of Soils, D854-58 (American Society on Testing Material, 1979), pp. 213-215.

3. L. K. Porter, W. D. Kemper, R. D. Jackson, and B. C. Stewart, "Chloride Diffusion in Soils is Influenced by Moisture Content," Soil Sci. Soc. Am. Proc. 24, 460 (1960). 
4. H. C. Claassen, "Water Quality and Physical Characteristics of Nevada Test Site Water-Supply Wells," US Geological Survey report USGS-474-158 (1973).

5. A. F. White, H. C. Claassen, and L. V. Benson, "The Effect of Dissolution of Volcanic Glass on the Water Chemistry in a Tuffaceous Aquifer, Rainier Mesa, Nevada," US Geological Survey Water-Supply paper 1535-Q (1980).

6. K. Wolfsberg, B. P. Bayhurst, B. M. Crowe, W. R. Daniels, B. R. Erdal, F. O. Lawrence, A. E. Norris, and J. R. Smyth, "Sorption-Desorption Studies on Tuff. I. Initial Studies with Samples from the J-13 Drill Site, Jackass Flats, Nevada," Los Alamos Scientific Laboratory report LA-7480-MS (April 1979).

7. E. N. Treher and N. A. Raybold, "The Elution of Radionuclides through Columns of Crushed Rock from the Nevada Test Site," Los Alamos National Laboratory report LA-9329-MS (October 1982).

8. D. Langmuir, "Uranium Solution-Mineral Equilibria at Low Temperatures with Applications to Sedimentary Ore Deposits," Geochim. Cosmochim. Acta 42, 547 (1978).

9. 1. Neretnieks, "Diffusion in the Rock Matrix - An Important Factor in Radionuclide Retardation?" J. Geophys. Res. 85, 4379 (1980). 